\title{
Metal Oxide Nanoparticles/Multi-walled Carbon Nanotube Nanocomposite Modified Electrode for the Detection of Dopamine: Comparative Electrochemical Study \\ Omolola E Fayemi ${ }^{1,2}$, Abolanle S Adekunle ${ }^{1,2,3}$ and Eno E Ebenso ${ }^{1,2 *}$
}

${ }^{1}$ Department of Chemistry, School of Mathematical and Physical Sciences, Faculty of Agriculture, Science and Technology, North-West University (Mafikeng Campus), Private Bag X2046, Mmabatho 2735, South Africa

${ }^{2}$ Material Science Innovation and Modelling (MaSIM) Research Focus Area, Faculty of Agriculture, Science and Technology, North-West University (Mafikeng Campus), Private Bag X2046, Mmabatho 2735, South Africa

${ }^{3}$ Department of Chemistry, Obafemi Awolowo University, Ile-Ife, Nigeria

\begin{abstract}
Electrochemical properties and sensor application of multi-walled carbon nanotubes (MWCNTs), doped with metal oxides $\left[\left(\mathrm{MO}=\right.\right.$ nickel oxide $(\mathrm{NiO})$, zinc oxide $(\mathrm{ZnO})$ and iron oxide $\left.\left(\mathrm{Fe}_{3} \mathrm{O}_{4}\right)\right]$ nanoparticles was investigated using FTIR, XRD, UV-vis spectroscopy, Raman spectroscopy, TEM, SEM, EDX, and cyclic voltammetry techniques. Electrochemical oxidation of dopamine on a glassy carbon electrode (GCE) modified with multi-walled carbon nanotubes doped with metal oxides (GCE/MWCNT/NiO, GCE/MWCNT/ZnO, GCE/MWCNT/Fe $\mathrm{O}_{4}$ ) was examined by cyclic voltammetry, EIS and square wave voltammetry in $0.1 \mathrm{M}$ phosphate buffer solution PBS at pH 7 . The results were compared with those obtained on bare GCE, GCE/MWCNT and MO GCE modified electrodes (GCE/NiO, $\left.\mathrm{GCE} / \mathrm{ZnO}, \mathrm{GCE} / \mathrm{Fe}_{3} \mathrm{O}_{4}\right)$. All electrodes were conditioned at potential of $0.2 \mathrm{~V}(\mathrm{vs} \mathrm{Ag} / \mathrm{AgCl}$, sat'd $\mathrm{KCl}$ ) in DA solution for EIS experiment. It was found that the multi- walled carbon nanotubes improve remarkably the reactivity of $\mathrm{NiO}, \mathrm{ZnO}$ and $\mathrm{Fe}_{3} \mathrm{O}_{4}$ for dopamine oxidation. The GCE/MWCNT/NiO, GCE/MWCNT/ZnO, GCE/MWCNT/Fe $\mathrm{O}_{4}$ electrodes exhibited good linear properties in the concentration range from $4 \times 10^{-5} \mu \mathrm{M}$ to $6.25 \mu \mathrm{M}$ for the quantitative analysis of dopamine (DA) with a limit of detection of $7.99 \times 10^{-12} \mathrm{M}, 3.742 \times 10^{-7} \mathrm{M}$ and $1.386 \times 10^{-6} \mathrm{M}$ respectively. The limit of detection of GCE/MWCNT/NiO was better than the other two nanocomposites modified electrodes. The interference study also revealed no AA interference signal at AA concentration 1000 times that of DA. The DPV techniques give well distinct peaks for the DA and AA and a wider separation potential. The prepared electrode exhibited satisfactory stability and long shelf life when stored at ambient conditions. It has been demonstrated that the GCE/MWCNT/NiO modified electrode can be successfully used for the assay of dopamine in some real samples.
\end{abstract}

Keywords: Nanoparticles; Nickel oxide; Zinc oxide; Iron oxide; Multi-walled carbon nano- tubes; Glassy carbon electrode; Dopamine; Cyclic voltammetry; Square wave voltammetry

\section{Introduction}

There is significant interest in developing electrochemical techniques for determination of neurotransmitters such as dopamine (DA). DA is ever-present neurotransmitter in mammalian brain tissues that plays an important physiological role in the functioning of central nervous, renal, hormonal and cardiovascular systems as an extra cellular chemical messenger [1,2]. DA belongs to the family of inhibitory neurotransmitters; its function is to regulate neural interactions by reducing the permeability of gap junctions between adjacent neurons of the same type. In addition, neuro degeneration of DA-containing neurons contributes to late-onset neurological diseases, including Parkinson's and Alzheimer's diseases, and possibly to normal ageing of the brain [3]. Besides, numerous reports have shown its coexistence in biological systems $[4,5]$. Therefore investigation of neurological behavior and also simultaneous determination of DA is of great importance for the elucidation of its precise physiological functions.

A range of analytical techniques such as chromatographic methods, mass spectroscopy [6], spectrophotometry [7] and chemiluminesence [8] are reported in the literature for detection of DA. However these methods suffer from some disadvantages including long analysis times, high costs, the requirement for sample pretreatment, and in some cases low sensitivity and selectivity. These disadvantages probably make them unsuitable for routine analysis. The advantages of electrochemical methods for determination of DA include low cost, high sensitivity and short measurement time. However, the electrochemical measurement of neurotransmitter concentrations has been mainly unsatisfactory due to the inability of the electrodes employed to separate the potentials of these species sufficiently to allow for accurate detection. Ascorbic acid (AA) is usually present in vivo at concentrations 100-1000 times higher than the neurotransmitters. Obviously, it is necessary to develop selective and sensitive techniques to resolve these problems. Therefore, various electrochemical approaches have been made to overcome these difficulties for the determination of DA [9-14].

The attractive features of the multi-walled carbon nano-tubes (MWCNTs) including their unique mechanical and electrical properties are significant advantages in the design and development of

*Corresponding author: Eno E Ebenso, Department of Chemistry, Schoo of Mathematical and Physical Sciences, Faculty of Agriculture, Science and Technology, North-West University (Mafikeng Campus), Private Bag X2046 Mmabatho 2735, South Africa, Tel: +27183892050/2051; Fax: +27183892052 E-mail: Eno.Ebenso@nwu.ac.za

Received August 18, 2015; Accepted November 12, 2015; Published Novembe 22, 2015

Citation: Fayemi OE, Adekunle AS, Ebenso EE (2015) Metal Oxide Nanoparticles/ Multi-walled Carbon Nanotube Nanocomposite Modified Electrode for the Detection of Dopamine: Comparative Electrochemical Study. J Biosens Bioelectron 6: 190. doi:10.4172/2155-6210.1000190

Copyright: $\odot 2015$ Fayemi OE, et al. This is an open-access article distributed under the terms of the Creative Commons Attribution License, which permits unrestricted use, distribution, and reproduction in any medium, provided the original author and source are credited. 
Citation: Fayemi OE, Adekunle AS, Ebenso EE (2015) Metal Oxide Nanoparticles / Multi-walled Carbon Nanotube Nanocomposite Modified Electrode for the Detection of Dopamine: Comparative Electrochemical Study. J Biosens Bioelectron 6: 190. doi:10.4172/2155-6210.1000190

Page 2 of 14

the electrochemical sensors [13-15]. Furthermore, MWCNTs modified by the adsorption of small organic molecules or metal nanoparticles via redox or electro-deposition can be used to determine $\mathrm{H}_{2} \mathrm{O}_{2}$ iodate dopamine (DA), organic small molecules, inorganic ion and even widely used as catalytic electrodes of fuel cells [16-25]. Multiwalled carbon nanotubes (MWCNT)-modified glassy carbon electrodes GCEs exhibited signals enhanced by about five-fold in the detection of dopamine in the presence of AA [26]. Jacobs et al. [27] reviewed the use of MWCNTs to obtain enhanced signals in the detection of substances such as carbohydrates, nucleic acids, glucose, pesticides, and serotonin, with similar reports relating to trace metals [28] and nitroaromatic compounds [29]. There are several literatures on the electro-oxidation of dopamine on modified electrodes [30-34].

For example, Yang-Rae Kim et al. developed a graphene modified electrode (GME) by drop- casting graphene on glassy carbon electrode. The graphene modified electrode showed an increased current intensity compared with glassy carbon electrode and graphite modified electrode and detect DA successfully in the presence of AA [30]. Chuan-yin Liu et al. fabricated $\mathrm{Cu}-\mathrm{Ni}(\mathrm{OH})_{2} / \mathrm{N}-\mathrm{GR} / \mathrm{Nafion} / \mathrm{GCE}$ sensor been prepared by electrodeposition and the proposed modified GCE was used for the determination of DA in simulated samples and DA injections with favourable recoveries [31]. The electrocatalytic oxidation of dopamine (DA) at a home-made aluminum electrode modified with nickel pentacyanonitrosylferrate (NiPCNF) film was studied by Razmi et al. [32]. The NiPCNF films, formed on the Al electrode show excellent electrocatalytic activity toward the oxidation of DA. Kangbing et al. reported a chemically modified electrode based on the carbon nanotube film-coated glassy carbon electrode (GCE) for the simultaneous determination of dopamine (DA) and serotonin (5-HT) and lowers oxidation overpotentials [33]. Adekunle et al. reported chemical deposition of Prussian blue (PB) nanoparticles and polyaminobenzene sulphonated single- walled carbon nanotubes (SWCNTPABS) on edged plane pyrolytic graphite electrode (EPPGE) and used the obtained EPPGE-SWCNT-PB for dopamine sensing. Results showed that EPPGE-SWCNT-PB electrode gave the best dopamine (DA) current response, which increases with increasing $\mathrm{PB}$ layers [34].

Despite this huge literature, and to the best of our knowledge this work represent the first time an extensive comparative study on the electrocatalytic properties of oxides of three transition metals nanoparticles $\left(\mathrm{NiO}, \mathrm{ZnO}\right.$ and $\left.\mathrm{Fe}_{3} \mathrm{O}_{4}\right)$ integrated with MWCNTs towards dopamine oxidation will be carried out. In addition, this study also provides report on the extent and mechanism of electron transport of the different metal oxides $\left(\mathrm{NiO}, \mathrm{ZnO}\right.$ and $\mathrm{Fe}_{3} \mathrm{O}_{4}$ ) nanoparticles and their nanocomposite with MWCNT, and their interaction with dopamine at physiological $\mathrm{pH}$ condition. GCE-MWCNT-NiO electrode has proven to be the best electrode in terms of DA oxidation current and nano molar limit of detection. DA and ascorbic acid (AA) signal were well resolved using SWV and DPV techniques compared to CV technique, with DPV giving the best peak separation of $400 \mathrm{mV}$, $300 \mathrm{mV}$ and $600 \mathrm{mV}$ at GCE-MWCNT-NiO, GCE-MWCNT-ZnO and GCE-MWCNT- $\mathrm{Fe}_{3} \mathrm{O}_{4}$ electrodes respectively. The fabrication of this electrode is simple and, more importantly, provides welldefined voltammograms for catalytic detection of dopamine, as well as simultaneous detection of dopamine in the presence of ascorbic acid. Dopamine real sample analysis using the developed sensors was also carried out and reported.

\section{Experimental Details}

\section{Materials and reagents}

The pristine multi-walled carbon nanotubes (MWCNTs), was obtained commercially from Aldrich chemicals. A working Glassy carbon electrode (GCE, $3 \mathrm{~mm}$ diameter), $\mathrm{Ag} / \mathrm{AgCl}$, sat'd $\mathrm{KCl}$ reference electrode and a platinum disk counter electrode (99.999\%) were purchased from $\mathrm{CH}$ Instrument Inc., US. The salts of the metals, nickel nitrate hexahydrate $\left(\mathrm{Ni}\left(\mathrm{NO}_{3}\right)_{2} \cdot 6 \mathrm{H}_{2} \mathrm{O}\right)$; iron (III) chloride $\mathrm{FeCl}_{3}$, zinc nitrate hexahydrate $\mathrm{Zn}(\mathrm{NO})_{2} \cdot 6 \mathrm{H}_{2} \mathrm{O}$ were obtained from Sigma-Aldrich. Dopamine-hydrochloride $\left(\mathrm{C}_{8} \mathrm{H}_{11} \mathrm{NO}_{2} \cdot \mathrm{Hcl}\right)$ was also obtained from Sigma chemicals. Sodium sulphate $\left(\mathrm{Na}_{2} \mathrm{SO}_{3}\right)$; sodium hydroxide $(\mathrm{NaOH})$; hydrated potassium hexacyano ferrate (II) $\left(\mathrm{K}_{4}\left[\mathrm{Fe}(\mathrm{CN})_{6}\right] .6 \mathrm{H}_{2} \mathrm{O}\right)$; potassium hexacyano ferrate $(\mathrm{III})\left(\mathrm{K}_{3} \mathrm{Fe}(\mathrm{CN})_{6}\right)$; dimethylformamide $\left.\left(\mathrm{CH}_{3}\right)_{2} \mathrm{NC}(\mathrm{O}) \mathrm{H}\right)$; acetone $\left(\mathrm{C}_{3} \mathrm{H}_{3} \mathrm{O}\right)$; ethanol $\left(\mathrm{C}_{2} \mathrm{H}_{5} \mathrm{OH}\right)$; ammonia solution $\left(\mathrm{NH}_{3} \cdot \mathrm{H}_{2} \mathrm{O}\right)$; and other reagent were of analytical grade and were obtained from Sigma-Aldrich and Merck chemicals respectively. Dopamine drug (Dopamine HCl- Fresenius ${ }^{\circ}$ (200 mg/5 ml) product of Bodene (pty) Ltd South Africa, was obtained from a local pharmacy stored for life sample analysis. Ultra-pure water of resistivity $18.2 \mathrm{M} \Omega \mathrm{cm}$ was obtained from a Milli-Q Water System (Millipore Corp., Bedford, MA, USA) and was used throughout for the preparation of solutions. $0.1 \mathrm{M}$ phosphate buffer solutions of pH 7 was prepared using sodium hydrogen phosphate di-hydrate $\left(\mathrm{NaH}_{2} \mathrm{PO}_{4} \cdot 2 \mathrm{H}_{2} \mathrm{O}\right)$ and di-sodium hydrogen phosphate di-hydrate $\left(\mathrm{Na}_{2} \mathrm{HPO}_{4} \cdot 2 \mathrm{H}_{2} \mathrm{O}\right)$ or their potassium salts. The $\mathrm{pH}$ was adjusted with 0.1 $\mathrm{M} \mathrm{H}_{3} \mathrm{PO}_{4}$ or $\mathrm{NaOH}$. All solutions were prepared using double distilled deionised water and purged with pure nitrogen to eliminate oxygen and any form of oxidation during experiment. All other reagents were of analytical grades and were used directly as received from the suppliers without further purification. All electrochemical experiments will be performed with nitrogen

\section{Preparation of metal oxides nanoparticles}

Nickel oxide nanoparticle: In a typical procedure, $291 \mathrm{mg} \mathrm{Ni}$ $\left(\mathrm{NO}_{3}\right)_{2} \cdot 6 \mathrm{H}_{2} \mathrm{O}$ was dissolved in $10 \mathrm{ml}$ water. Then, concentrated ammonia solution was added until formation of $\mathrm{Ni}(\mathrm{OH})_{2}$. The precipitate colour was light green. Addition of ammonia solution was continued just to dissolve $\mathrm{Ni}(\mathrm{OH})_{2}$ and form dark blue nickel-ammonia complex with a solution $\mathrm{pH}$ of $\approx 10$. This solution was then placed near a baker containing $10 \mathrm{ml}$ concentrated sulphuric acid in a closed polyethylene container for $48 \mathrm{~h}$ at room temperature. A light green powder was precipitated. The product was washed with distilled water and ethanol and dried at $40^{\circ} \mathrm{C}$ to obtain the nickel oxide nanoparticles [35].

Zinc oxide nanoparticle: The production unit of $\mathrm{ZnO}$ nanostructures consists basically of a jacketed three-neck glass flask and of a magnetic stirrer with temperature control. In the three-neck glass flask, $\mathrm{NaOH}$ was dissolved in deionized water to a concentration of $1.0 \mathrm{M}$ and the resulting solution was heated, under constant stirring, to the temperature of $70^{\circ} \mathrm{C}$. After achieving this temperature, a solution of $0.5 \mathrm{M} \mathrm{Zn}\left(\mathrm{NO}_{3}\right)_{2} \cdot 6 \mathrm{H}_{2} \mathrm{O}$ was added slowly (dripped for 60 minutes) into the three- neck glass flask containing the $\mathrm{NaOH}$ aqueous solution under continual stirring. In this procedure the reaction temperature was constantly maintained at $70^{\circ} \mathrm{C}$.

The suspension formed with the dropping of $0.5 \mathrm{MZn}\left(\mathrm{NO}_{3}\right) 2.6 \mathrm{H}_{2} \mathrm{O}$ solution to the alkaline aqueous solution was kept stirred for two hours at the temperature of $70^{\circ} \mathrm{C}$. The material formed was filtered and washed several times with deionized water. The washed sample was dried at $65^{\circ} \mathrm{C}$ in oven for several hours [36]. 
Citation: Fayemi OE, Adekunle AS, Ebenso EE (2015) Metal Oxide Nanoparticles / Multi-walled Carbon Nanotube Nanocomposite Modified Electrode for the Detection of Dopamine: Comparative Electrochemical Study. J Biosens Bioelectron 6: 190. doi:10.4172/2155-6210.1000190

Iron (III) oxide nanoparticle: $30 \mathrm{ml}$ of $2 \mathrm{~mol} \mathrm{dm}^{-3} \mathrm{FeCl}_{3}$ stock solutions, $20 \mathrm{ml}$ of $1 \mathrm{~mol} \mathrm{dm}^{-3} \mathrm{Na}_{2} \mathrm{SO}_{3}$ stock solution, and $50.8 \mathrm{ml}$ of concentrated ammonia diluted to a total volume of $800 \mathrm{ml}$ were used. Just after the mixing of $\mathrm{FeCl}_{3}$ and $\mathrm{Na}_{2} \mathrm{SO}_{3}$, the color of the solution in the smaller beaker could be seen to alter from light yellow to red, indicating formation of complex ions. This solution was poured quickly into the diluted ammonia solution under vigorous stirring when the color changed from red to yellow again. A black precipitate formed. Stirring was continued for $30 \mathrm{~min}$. After the reaction, the beaker containing the suspension was placed on a permanent magnet. Black powders could be seen to quickly settle on the bottom of the beaker. The supernatant was discarded and fresh water was added to the beaker; this procedure was repeated several times until most of the ions in the suspension were removed. Dry powders were obtained by filtering and drying at room temperature [37].

\section{Preparation of catalysts}

$2 \mathrm{mg}$ of MWCNT in $2 \mathrm{ml}$ DMF was weighed and doped with 2.5 mg of metal oxides $\mathrm{NiO}$ nanoparticles. The mixture was stirred for 72 hrs at room temperature. The known volume of the putty formed of the MWCNT-NiO nanocomposites was dried at $25^{\circ} \mathrm{C}$ overnight for the solvent to evaporate.

\section{Preparation of modified GC electrode}

The GC electrode was polished with $0.3 \mu \mathrm{m}$ and $0.05 \mu \mathrm{m}$ alumina slurries for $3 \mathrm{~min}$ each, followed by thorough rinsing with water, and sonicating in turn with distilled water, ethanol and distilled water for $3 \mathrm{~min}$ each before modification. The electrodes were prepared by a drop-dry method. About $20 \mu \mathrm{L}$ drop of $\mathrm{MO}\left(\mathrm{MO}=\mathrm{NiO}, \mathrm{Fe}_{3} \mathrm{O}_{4}, \mathrm{ZnO}\right)$, MWCNT and MWCNT-MO (2mg acidified MWCNTs and $2.5 \mathrm{mg}$ $\mathrm{MO}$ in $1 \mathrm{ml} \mathrm{DMF}$ ) were dropped on the bare GCE and dried in an oven at $50^{\circ} \mathrm{C}$ for about $2 \mathrm{~min}[38,39]$. The obtained GCE-NiO, GCE$\mathrm{ZnO}, \mathrm{GCE}-\mathrm{Fe}_{3} \mathrm{O}_{4}$, GCE-MWCNT, and GCE-MWCNT-NiO, GCEMWCNT-ZnO and GCE-MWCNT- $\mathrm{Fe}_{3} \mathrm{O}_{4}$ were characterised by cyclic voltammetry using $5 \mathrm{mM}$ potassium ferricyanide solution prepared in $0.1 \mathrm{M}$ PBS at $\mathrm{pH} 7$ as a redox probe.

\section{Characterization}

Infrared spectroscopy data were obtained with PerkinElmer GX 2000 FT-IR Spectrometer attached to a PerkinElmer Auto Image Microscope System equipped with liquid nitrogen cooled MCT detector. The samples were analyzed using $\mathrm{KBr}$ in the transmission mode. Field emission scanning electron microscopy (FESEM) images were obtained from JEOL JSM $5800 \mathrm{LV}$ (Japan) while the energy dispersive $\mathrm{x}$-ray spectra (EDX) were obtained from NORAN VANTAGE EDX (USA). TEM experiments were performed using a Model JEOL JEM-2100F field emission transmission electron microscope, Tokyo (Japan). UV/ Vis experiment were performed with a UV-Visible spectrophotometer, 100 Bio Varian Win UV, Australia. Raman measurements were carried out in Renishaw InVia model spectrometer with the laser excitation of $514 \mathrm{~nm}$. Powder X-ray diffraction (XRD) study was performed on XPERT-PRO diffractometer operating at $40 \mathrm{kV}$ and $30 \mathrm{~mA}$, using $\mathrm{Cu}$ $\mathrm{Ka}$ radiation. Electrochemical experiments were carried out using an AUTOLAB Potentiostat PGSTAT 302 (Eco Chemie, Utrecht, and The Netherlands) driven by the GPES software version 4.9. Electrochemical impedance spectroscopy (EIS) measurements were performed with an AUTOLAB Frequency Response Analyser (FRA) software between $1.0 \mathrm{~Hz}$ and $10 \mathrm{kHz}$ using a $5 \mathrm{mV}$ rms sinusoidal modulation with a solution of $5 \mathrm{mM}$ of $\mathrm{K}_{4} \mathrm{Fe}(\mathrm{CN})_{6}$ and a $5 \mathrm{mM} \mathrm{K}_{3} \mathrm{Fe}(\mathrm{CN})_{6}(1: 1)$ mixture in phosphate buffer solution (PBS) of $\mathrm{pH} 7.0$ and at the E1/2 of the
$\left[\mathrm{Fe}(\mathrm{CN})_{6}\right]^{4-} /\left[\mathrm{Fe}(\mathrm{CN})_{6}\right]^{3-}(0.3 \mathrm{~V}$ vs. $\mathrm{Ag} \mid \mathrm{AgCl}$ in sat'd $\mathrm{KCl})$. Bare or modified glassy carbon electrode (GCE) disk $(d=3.0 \mathrm{~mm}$ in Teflon) was used as the working electrode. A bench top pH/ISE ORION meter, model $420 \mathrm{~A}$, was used for $\mathrm{pH}$ measurements. All solutions were deaerated by bubbling nitrogen prior to each electrochemical experiment. Experiments were performed at $25 \pm 1^{\circ} \mathrm{C}$.

\section{Electrochemical studies}

The modified GCE was characterized by cyclic voltammetry (CV) and electrochemical impedance spectroscopy (EIS) in $0.1 \mathrm{~mol} / \mathrm{L}$ PBS containing $5 \mathrm{mM} \mathrm{Fe}(\mathrm{CN})_{6}{ }^{3-14-}$. The potential was set at $0.2 \mathrm{~V}$ in the frequency range from $10 \mathrm{kHz}$ to $1 \mathrm{~Hz}$ for the EIS study. Electrochemical oxidation of DA was investigated in $\mathrm{pH}$ 7.0 PBS using cyclic voltammetry and square wave voltammetry (SWV). The interference studies were carried out by using SWV, DPV and chronoamperometric techniques. Frequencies used for square wave voltammetry typically range from approximately $1 \mathrm{~Hz}$ to $120 \mathrm{~Hz}$. DPV provides the necessary resolving power, by suppressing background currents, which give rise to well defined peak separation. The DPV and SWV experiments were carried out using GCE- MWCNT-NiO, GCE-MWCNT-ZnO and GCE-MWCNT- $\mathrm{Fe}_{3} \mathrm{O}_{4}$ in $\mathrm{pH}$ 7.0 PBS containing $10^{-2} \mathrm{M}$ AA and $10^{-4}$ $\mathrm{M}$ DA solutions respectively. All the electrochemical experiments were carried out at room temperature and distil-deionised water was used throughout

\section{Preparation of the dopamine hydrochloride injection solution}

A $2 \mathrm{ml}$ of the drug (dopamine hydrochloride injection-Dopamine HCl-Fresenius ${ }^{\circledast}$ ) sample was diluted to $100 \mathrm{ml}$ with distilled de-ionised water. $2 \mathrm{~mL}$ of the diluted solution was pipette into five $50 \mathrm{ml}$ volumetric flask and all except one were spiked with different concentration of standard dopamine solution, and made to volume with phosphate buffer $\mathrm{pH}$ 7.0. The concentration of each test aliquot solution was determined using square wave voltammetry. Four different injections from the same batch were analysed using the same procedure. The experiment was repeated 3 times for each sample.

\section{Results and Discussion}

\section{Characterization of the electrodes}

Morphological characterization: The surface morphology of the material was examined with SEM and transmission electron microscope (TEM). TEM/SEM samples were prepared for electron microscopy by drop-dried the sample on a glass plate and mounting on the SEM stubs using double-sided graphite tape, and then sputter coated with gold using a Balzers' union sputtering device. The samples were viewed using a TESCAN Vega TS 5136LM typically at $20 \mathrm{kV}$ at a working distance of $20 \mathrm{~mm}$. Figure 1a (i-iv) shows TEM images of the MWCNT and metal oxides nanoparticles. Unlike the MWCNT with disperse spiral tubes (Figure 1a (i)), the TEM images of the metal oxide nanoparticles were porous, crystalline and somewhat aggregated, possibly due to ineffective dispersing capability of the solvent. TEM image of $\mathrm{ZnO}$ nanoparticles (Figure 1a (iv)) shows dark layers of several nanoparticles on top of one another and they have either spherical or rod-like structure. The average diameter of MWCNT nanoparticles is about 8-11 nm. The relatively mono disperse $\mathrm{Fe}_{3} \mathrm{O}_{4}$ particles have an average diameter of $10 \mathrm{~nm}$. The sizes of $\mathrm{ZnO} N P$ were $50 \pm 15 \mathrm{~nm}$. (Figure 1)

The SEM images of MWCNT and the synthesised metal oxide nanoparticles were represented in Figure 1b (i-iv). Figure 1b (i) 
Citation: Fayemi OE, Adekunle AS, Ebenso EE (2015) Metal Oxide Nanoparticles / Multi-walled Carbon Nanotube Nanocomposite Modified Electrode for the Detection of Dopamine: Comparative Electrochemical Study. J Biosens Bioelectron 6: 190. doi:10.4172/2155-6210.1000190

show the SEM image for the carbon nanotube materials, showing the appearance of loose curly CNTs together with some amorphous-like particles. These nanotubes seemingly have a broad length distribution. The nanotube diameters range from 20 to $60 \mathrm{~nm}$. The SEM image Figure $1 \mathrm{~b}$ (ii) indicates the formation of a flower-like conglomerate structures nickel oxide nanoparticles. Figure $1 \mathrm{~b}$ (iii) shows a aggregated
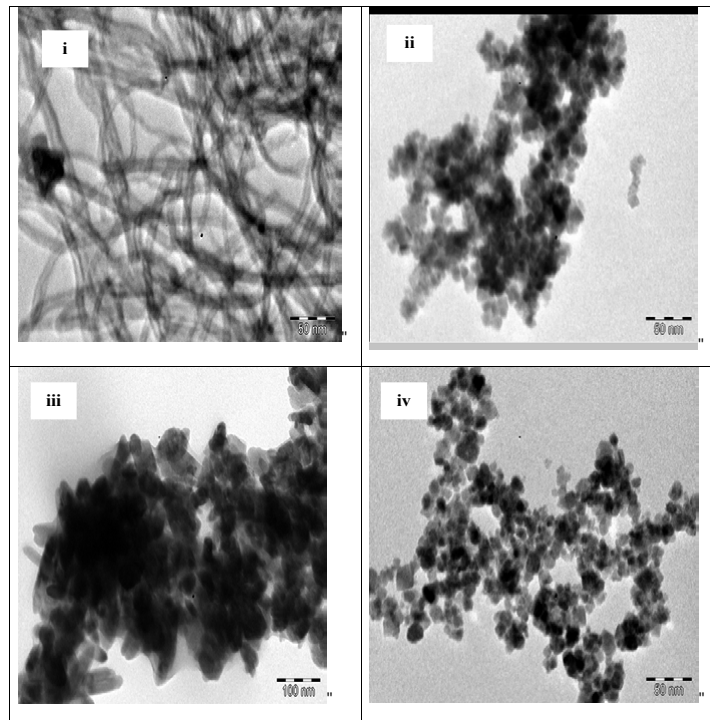

Figure 1a: Typical TEM images of (i) MWCNT (ii) $\mathrm{NiO}$ (iii) $\mathrm{Fe}_{3} \mathrm{O}_{4}$ and (iv) $\mathrm{ZnO}$ nanoparticles.
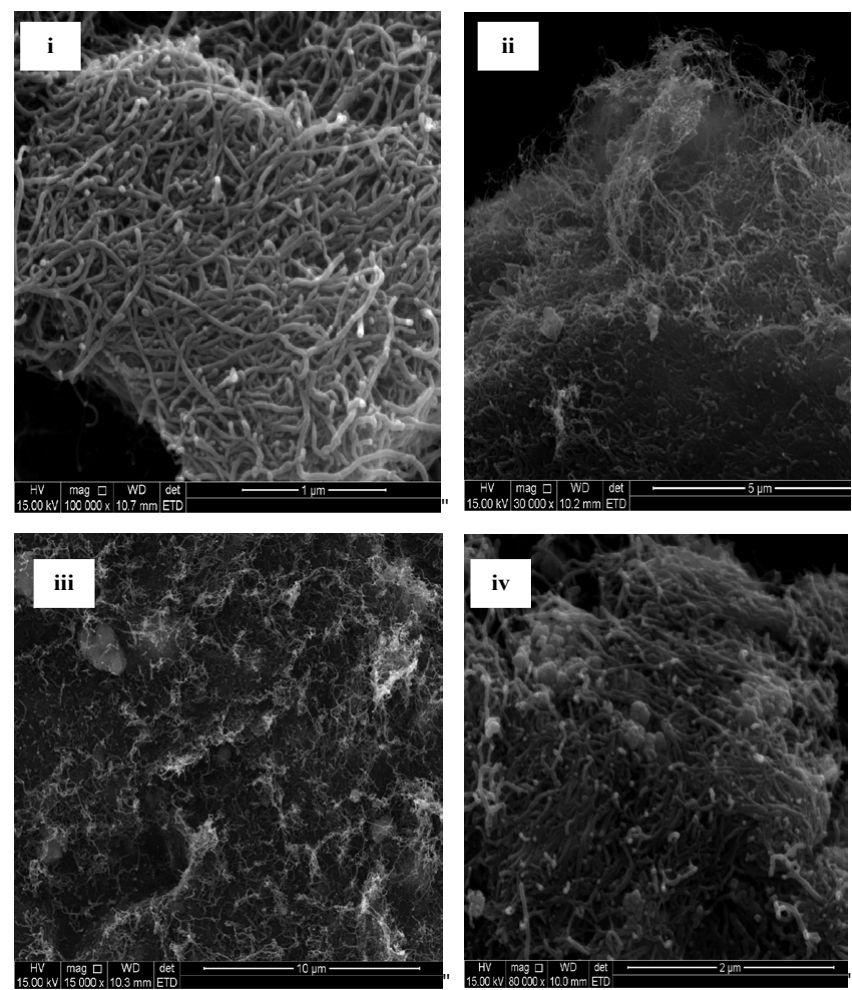

Figure 1b: Typical SEM images of (i) MWCNT (ii) MWCNT-NiO (iii) MWCNT$\mathrm{ZnO}$ and (iv) MWCNT-Fe $\mathrm{O}_{4}$ nanoparticles.
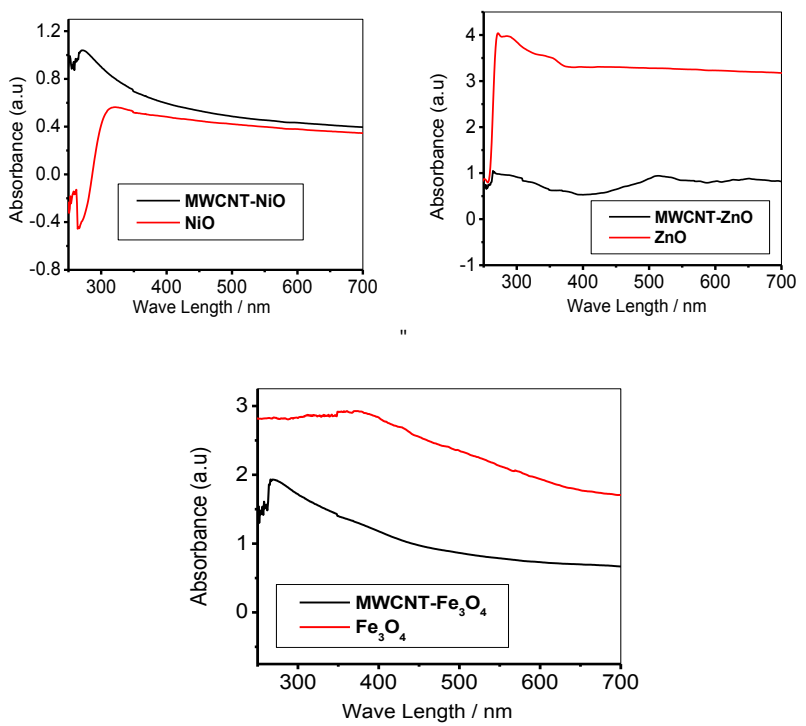

Figure 2: The UV-vis spectra of metal oxide nanoparticles and MWCNT-MO nanocomposites.

$\mathrm{ZnO}$ microstructures. It can be clearly seen that the flower is made of taper shape rods that are $400-500 \mathrm{~nm}$ long and $100-150 \mathrm{~nm}$ thick. The $\mathrm{Fe}_{3} \mathrm{O}_{4}$ particle (Figure $1 \mathrm{~b}(\mathrm{iv})$ ) showed an aggregated film probably due to the method of preparation. The average sizes of $\mathrm{Fe}_{3} \mathrm{O}_{4}$ nanoparticles are estimated to be $40-100 \mathrm{~nm}$.

UV-vis study: The optical absorption spectrum of nickel oxide nanoparticle is shown in Figure 2. It can be seen that the strongest absorption peak of the $\mathrm{NiO}$ sample appears at around $330 \mathrm{~nm}$, which is closer to 355 and $320 \mathrm{~nm}$ reported for $\mathrm{NiO}$ nanoparticles [40,41]. The different in absorption bands can be attributed to the different methods of preparation of the nanoparticles. The absorption bands at $330 \mathrm{~nm}$ for the $\mathrm{NiO}$ shifted to lower absorption band at around 280 $\mathrm{nm}$ in the presence of MWCNT suggesting the successful formation of MWCNT-NiO nanocomposite.

The Uv-vis absorption spectrum of $\mathrm{ZnO}$ sample shows excitonic peak with absorbance intensity at wavelength of $280 \mathrm{~nm}$. Another absorption peak observed at around $350 \mathrm{~nm}$ is characteristic of $\mathrm{ZnO}$ nanoparticles [42]. For $\mathrm{ZnO}$ of wide band $\mathrm{Gap}$ of $3.37 \mathrm{eV}$, an absorption peak is expected at $\sim 358 \mathrm{~nm}$ [43]. In the MWCNT-ZnO nanocomposite, aside the $\mathrm{ZnO}$ absorption bands at $350 \mathrm{~nm}$ two new absorption bands emerged at around 530 and $650 \mathrm{~nm}$ respectively and a reduction in the $\mathrm{ZnO}$ band intensity also confirming successful transformation of $\mathrm{ZnO}$ to MWCNT-ZnO nanocomposite. The Uv-vis absorption spectrum of $\mathrm{Fe}_{3} \mathrm{O}_{4}$ sample shows broad absorption peak ranging from 350 to 400 $\mathrm{nm}$ and was suggested to originate primarily from the absorption and scattering of light by magnetic nanoparticles. This observed absorption peak is in accordance with the literatures [44]. The high absorption band at $385 \mathrm{~nm}$ could indicate the formation of a least agglomerated nanosize particle which was observed at $410 \mathrm{~nm}$ in a related study [45]. However in the MWCNT- $\mathrm{Fe}_{3} \mathrm{O}_{4}$ nanocomposite, a shift in the absorption band of $\mathrm{Fe}_{3} \mathrm{O}_{4}$ at $350 \mathrm{~nm}$ to $280 \mathrm{~nm}$, plus reduction in the $\mathrm{Fe}_{3} \mathrm{O}_{4}$ band intensity further confirm the transformation of $\mathrm{Fe}_{3} \mathrm{O}_{4}$ to MWCNT- $\mathrm{Fe}_{3} \mathrm{O}_{4}$ nanocomposite. From the results, it can be observed that the UV absorption ability of MWCNT-MO nanocomposite decreased as demonstrated by reduction in the band intensity of the MO nanoparticles after incorporated into MWCNT. This behaviour 
has been described previously by authors as the characteristic of the adsorption of the assembled CNTs [46]. It can also be attributed to the smooth and pure nature of the MWCNTs, with the absence of other light absorbing groups that may lead to an increased absorption band. (Figure 2)

Raman and FTIR spectra: Figure 3a shows the Raman spectra of MWCNT and the metal oxide nanoparticles synthesized in this study. The Raman spectra of MWCNTs showed two charateristics sharp peaks at 1600 and $1380 \mathrm{~cm}^{-1}$ respectively. The sharp band at 1600 $\mathrm{cm}^{-1}$ ( $\mathrm{G}$ band) is attributed to the in-plane vibration of the $\mathrm{C}-\mathrm{C}$ bond [47], while the band at $1380 \mathrm{~cm}^{-1}$ (D band) is attributed to activation by the presence of disorder in carbon systems [48]. The Raman spectrum of $\mathrm{NiO}$ nanoparticles exhibited a strong, broad peak at 550 to $600 \mathrm{~cm}^{-1}$ which is due to the $\mathrm{NiO}$ stretching mode, also reported at $518 \mathrm{~cm}^{-1}$ for $\mathrm{NiO}$ in another study [49]. The Raman spectrum of $\mathrm{Fe}_{3} \mathrm{O}_{4}$ showed a strong band at $667 \mathrm{~cm}^{-1}$ which is characteristic of $\mathrm{Fe}_{3} \mathrm{O}_{4}$ nanoparticles [50]. The Raman spectrum of $\mathrm{ZnO}$ nanoparticles showed $\mathrm{ZnO}$ stretching modes at 442,571 and $1103 \mathrm{~cm}^{-1}$ characteristic of $\mathrm{ZnO}$ nanoparticles [51]. The Raman spectra for MWCNT-NiO and MWCNT-ZnO composite mixture show the characteristic bands observed in pure MWCNT ( $\mathrm{G}$ and $\mathrm{D}$ bands), disappearance of $\mathrm{NiO}$ and $\mathrm{ZnO}$ peaks, and formation of a well-defined and prominent peak at around $2800-3000 \mathrm{~cm}^{-1}$ confirming the successful formation of a new compound due to the interaction between the MO NPs and MWCNT. The Raman spectrum of MWCNT- $\mathrm{Fe}_{3} \mathrm{O}_{4}$ on the other hand showed the disappearance of the $\mathrm{Fe}_{3} \mathrm{O}_{4}$ peaks, a shift and drastic reduction in the intensity of the $\mathrm{G}$ and the D bands of the pure MWCNT, and an appearance of a new peak at around $500 \mathrm{~cm}^{-1}$ indicating the formation of the MWCNT- $\mathrm{Fe}_{3} \mathrm{O}_{4}$ composite. (Figure 3a)

The FTIR spectra showed several significant absorption peaks Figure $3 \mathrm{~b}$. The broad absorption band in the region of $500-600 \mathrm{~cm}^{-1}$ is assigned to $\mathrm{Ni}-\mathrm{O}, \mathrm{Zn}-\mathrm{O}$ and $\mathrm{Fe}-\mathrm{O}$ stretching vibration mode;
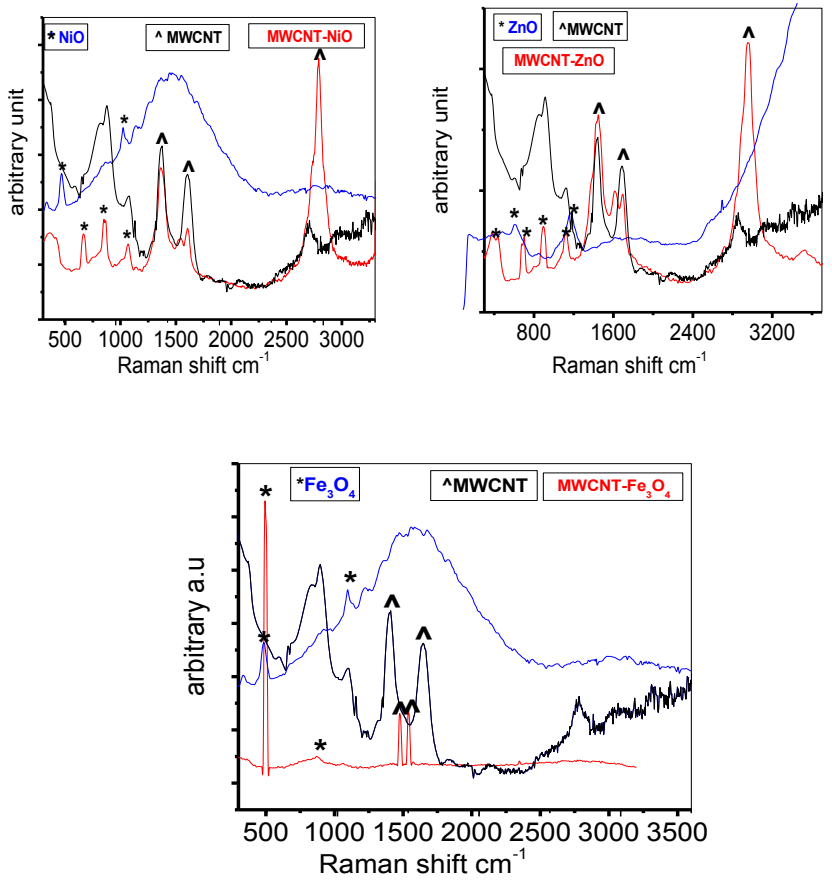

Figure 3a: The Raman Spectra of MWCNT, MO metal oxide nanoparticles, and MWCNT-MO nanocomposite.
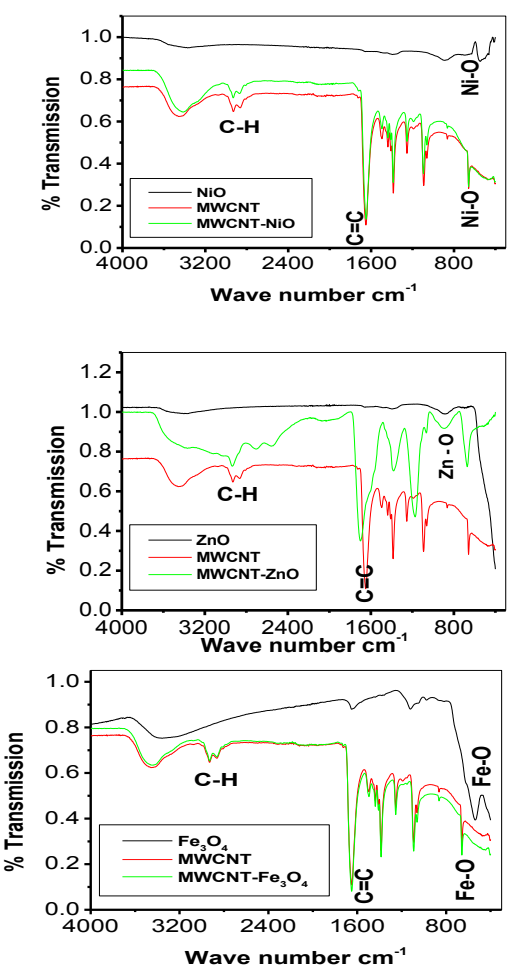

Figure 3b: Comparative FTIR Spectra of MWCNT, MO and MWCNT-MO nanocomposites.

the broadness of the absorption band indicates that the metal oxide powders are nanocrystals [52]. The weak band near $1635 \mathrm{~cm}^{-1}$ is assigned to $\mathrm{H}-\mathrm{O}-\mathrm{H}$ bending vibrations mode due to the adsorption of water in air during FTIR sample preparation. These observations provided the evidence to the effect of hydration in the structure. The serrated absorption bands in the region of $1000-1500 \mathrm{~cm}^{-1}$ are assigned to the $\mathrm{O}-\mathrm{C}=\mathrm{O}$ symmetric and asymmetric stretching vibrations and the $\mathrm{C}-\mathrm{O}$ stretching vibration, but the intensity of the band has weakened, which indicated that the ultrafine powers tend to strong physically adsorbed $\mathrm{H}_{2} \mathrm{O}$ and $\mathrm{CO}_{2}$ [53]. There are distinct absorption peaks at $1582,2920,2850$ and $3446 \mathrm{~cm}^{-1}$. The spectra show a band around 3446 $\mathrm{cm}^{-1}$ which can be attributed to the hydroxyl group $(v \mathrm{OH})$ of adsorbed water molecules. The band between $1582-1653 \mathrm{~cm}^{-1} \mathrm{can}$ be attributed to vibration mode of $\mathrm{C}=\mathrm{C}$ bonds of graphite in MWCNTs, while bands around 2920 and $2850 \mathrm{~cm}^{-1}$ are due to asymmetric and symmetric $\mathrm{C}-\mathrm{H}$ stretching in the MWCNTs. In the MWCNT-MO spectra, upon modification of the MO nanoparticles with MWCNT, the peaks around $500-600 \mathrm{~cm}^{-1}$ becomes more pronounced due to drastic reduction in the intensities of the MO peaks indicating that the MO have now been transformed to MWCNT-MO. There are also evidences of new peaks around $1200-1600 \mathrm{~cm}^{-1}$ in the MWCNT-MO nanocomposite but absent in $\mathrm{MO}$ nanoparticles alone. This is also an evidence of the successful formation of the MWCNT-MO nanocomposite through electrostatic interactions. (Figure $3 \mathrm{~b}$ )

EDX study: EDX spectra (supplementary Figure S1) show the elemental compositions of the MWCNT (i) and the synthesized metal oxide nanoparticles (ii - iv). The MWCNT spectrum is predominantly characterised with prominent carbon peak $(\mathrm{C}=92.22 \%)$. The prominence of nickel, zinc, iron and oxygen peaks in the EDX spectra of confirm the successful synthesis of $\mathrm{NiO}$ (ii), $\mathrm{ZnO}$ (iii), and $\mathrm{Fe}_{3} \mathrm{O}_{4}$ 

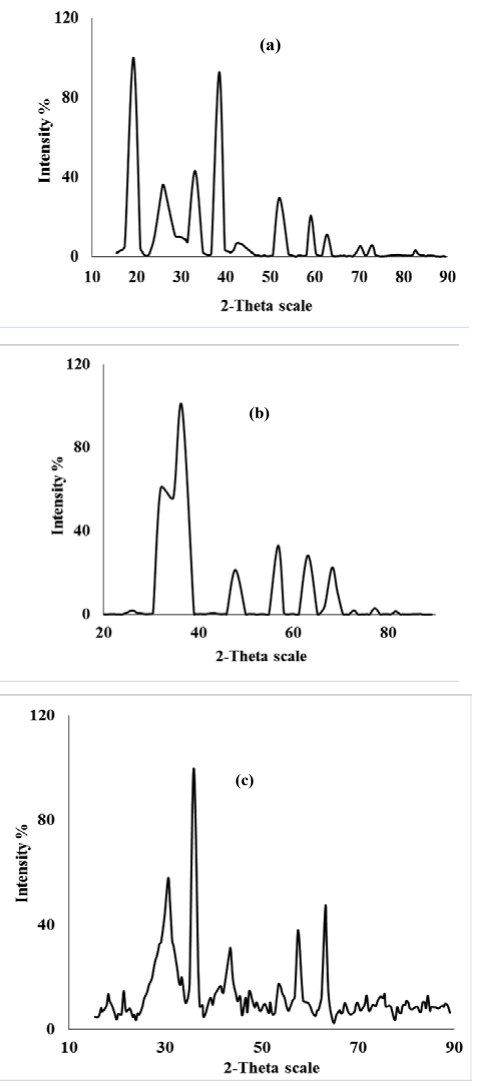

Figure 4: The typical XRD spectra of: (a) MWCNT-NiO (b) MWCNT-ZnO and (c) MWCNT- $\mathrm{Fe}_{3} \mathrm{O}_{4}$ nanocomposites.

(iv) nanoparticles. The elemental components for the metal oxides nanoparticles are $\mathrm{NiO}(\mathrm{Ni}=72.98 \%, \mathrm{O}=25.56 \%), \mathrm{ZnO}(\mathrm{Zn}=87.34 \%$, $\mathrm{O}=11.88 \%)$ and $\mathrm{Fe} 3 \mathrm{O} 4(\mathrm{Fe}=75.58 \%, \mathrm{O}=21.70 \%)$.

XRD: XRD analysis was used to determine the crystalline phase and the purity of the metal oxides nanoparticles incorporated into MWCNT (Figure 4). The results revealed that the nanocomposite formed were crystalline. Observed peaks diffraction indicated a high phase purity of metal oxide nanoparticles and also diffraction peaks at $2 \theta=26.3^{\circ}$ and $43.2^{\circ}$ corresponding to reflections of (002) and (100) crystallographic plates of MWCNT. In Figure 4, XRD analysis of the nanocomposites indicates that MWCNT is decorated with the metal oxides nanoparticles. The formation of MWCNT-NiO composites are confirmed by the presence of (002) plane of CNTs and 5 planes ofNiO in XRD spectra (Figure 4a) [54]. The formation of MWCNTZnO composites are characterized by the diffraction peaks situated at $2 \theta$ $=31.8^{\circ}, 34.5^{\circ}, 36.2^{\circ}, 47.5^{\circ}$ and $56.7^{\circ}$ corresponding to (100), (002), (101), (102) and (110) orientation planes of $\mathrm{ZnO}$ (Figure 4b) [55]. The diffraction lines typical of cubic crystal structures of magnetite are welldefined in the XRD pattern for $\mathrm{MWCNT}-\mathrm{Fe}_{3} \mathrm{O}_{4}$ (Figure 4c), therefore the formation of the nanocomposite is confirmed by diffraction peaks corresponding to (200), (220), (311), (400), (422), (511), (533) and (622) indicating a cubic crystal structure for the $\mathrm{Fe}_{3} \mathrm{O}_{4}$ anoparticles. These results demonstrate that the product is a mixture of two phases: cubic $\mathrm{Fe}_{3} \mathrm{O}_{4}$ and MWCNTs [56] (Figure 4).

\section{Electrochemical characterization of electrodes}

Scheme 1 is the schematic diagram summarising the electrochemical response of the GCE- MWCNT-MO electrodes in $\left.5 \mathrm{mM} \mathrm{Fe}(\mathrm{CN})_{6}\right]^{4-}$ / $\left[\mathrm{Fe}(\mathrm{CN})_{6}\right]^{3-}$ redox probe prepared in $0.1 \mathrm{M} \mathrm{PBS}$ at $\mathrm{pH} 7.0$, and in 0.1 mM DA prepared in $0.1 \mathrm{M}$ PBS ( $\mathrm{pH} 7.0$ ). The cyclic voltammograms study (scan rate, $25-1000 \mathrm{mVs}^{-1}$ ) of the bare GCE electrode in $0.1 \mathrm{M}$ PBS and $\left.5 \mathrm{mM} \mathrm{Fe}(\mathrm{CN})_{6}\right]^{4-} /\left[\mathrm{Fe}(\mathrm{CN})_{6}\right]^{3-}$ solution prepared in $0.1 \mathrm{M}$ PBS at $\mathrm{pH} 7$ is presented in Figure 5. The bare GCE did not show any peak in PBS (Figure 6a) while it showed a pair of redox peaks AA' in the regions of 0.16 and $0.24 \mathrm{~V}$ (attributed to the $\left.\mathrm{Fe}(\mathrm{CN})_{6}\right]^{4-} /\left[\mathrm{Fe}(\mathrm{CN})_{6}\right]^{3-}$ redox process $(E 1 / 2 \approx 0.2 \mathrm{~V}$ and $\Delta E \mathrm{p} \approx 0.1 \mathrm{~V}$ ) as shown in Figures $5 \mathrm{~b}$ and 6 . To evaluate the charge transfer properties of the GCE-MWCNT$\mathrm{MO}$ modified electrodes where $\mathrm{MO}$ represents $\mathrm{NiO}, \mathrm{ZnO}$ and $\mathrm{Fe}_{3} \mathrm{O}_{4}$ nanoparticles, we performed the cyclic voltammetry experiment for the modified electrodes in $\left.5 \mathrm{mM} \mathrm{Fe}(\mathrm{CN})_{6}\right]^{4-} /\left[\mathrm{Fe}(\mathrm{CN})_{6}\right]^{3-}$ in $0.1 \mathrm{M}$ PBS (scan rate, $25 \mathrm{mVs}^{-1}$ ) and the result is presented in Figure 6. Two pairs of redox peaks were observed for the $\mathrm{NiO}$ modified electrodes (Figure 6a). The first redox peaks AA' ranging from the regions of 0.0 to $400 \mathrm{mV}$ is attributed to the $\left.\mathrm{Fe}(\mathrm{CN})_{6}\right]^{4-} /\left[\mathrm{Fe}(\mathrm{CN})_{6}\right]^{3-}$ redox process. Similar redox peaks was observed in Figures $6 \mathrm{~b}$ and $6 \mathrm{c}$. Another pair of redox peaks $\mathrm{BB}^{\prime}$ in the regions of 543 and $491 \mathrm{mV}$ is attributed to $\mathrm{Ni}(\mathrm{II}) / \mathrm{Ni}(\mathrm{III})$ redox process. Second redox peaks BB' around $879 \mathrm{mV}$ attributed to $\mathrm{Zn}(\mathrm{II}) / \mathrm{Zn}$ (III) redox process was observed on the $\mathrm{ZnO}$ modified electrodes (Figure 6c). There is no observable peaks corresponding to $\mathrm{Fe}(\mathrm{II}) / \mathrm{Fe}$ (III) redox process on the $\mathrm{Fe}_{3} \mathrm{O}_{4}$ modified electrodes probably because of the faster electron transfer at the electrode, or overllap between the $\left.\mathrm{Fe}(\mathrm{CN})_{6}\right]^{4-} /\left[\mathrm{Fe}(\mathrm{CN})_{6}\right]^{3-}$ peaks and the $\mathrm{Fe}_{3} \mathrm{O}_{4}$ redox peaks. Generally, the GCE-MWCNT-NiO, GCE-MWCNT-ZnO and GCEMWCNT- $\mathrm{Fe}_{3} \mathrm{O}_{4}$ electrodes gave higher current response compared with bare GCE, GCE-MWCNT and GCE-MO $(\mathrm{MO}=\mathrm{NiO}, \mathrm{ZnO}$ $\left.\mathrm{Fe}_{3} \mathrm{O}_{4}\right)$ modified electrodes electrodes. Thus, the GCE- MWCNT-MO

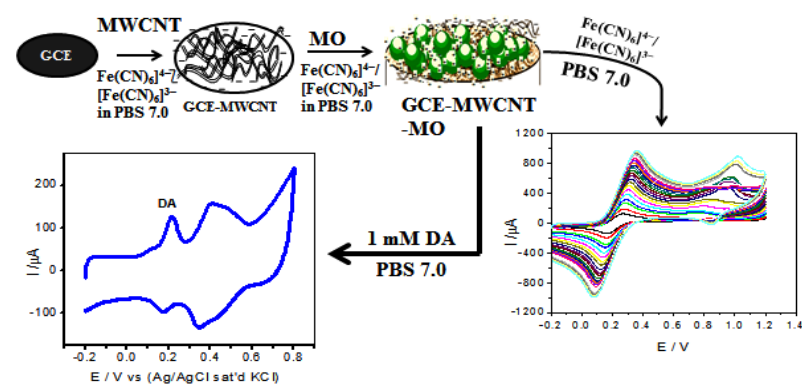

Scheme 1: Schematic diagram showing electrode modification procedure the electron transport and electrocatalytic behaviour of the GCE-MWCNT$\mathrm{MO}$ electrodes towards oxidation of dopamine.
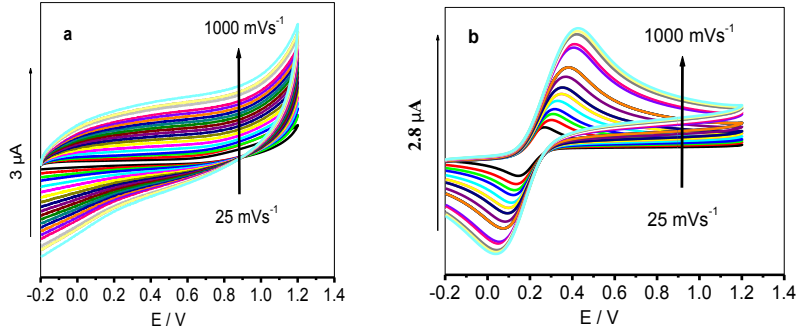

Figure 5: Cyclic Voltammograms of Bare GCE in (a) $0.1 \mathrm{M}$ PBS (pH 7) and (b) $\left.5 \mathrm{mM} \mathrm{Fe}(\mathrm{CN})_{6}\right]^{4-} /\left[\mathrm{Fe}(\mathrm{CN})_{6}\right]^{3-}$ solution prepared in $0.1 \mathrm{M}$ PBS (scan rate: 25-1000 $\mathrm{mVs}^{-1}$; inner to outer) 
Citation: Fayemi OE, Adekunle AS, Ebenso EE (2015) Metal Oxide Nanoparticles / Multi-walled Carbon Nanotube Nanocomposite Modified Electrode for the Detection of Dopamine: Comparative Electrochemical Study. J Biosens Bioelectron 6: 190. doi:10.4172/2155-6210.1000190

Page 7 of 14

electrodes have demonstrated faster charge transport behaviour in this study. (Figures 5 and 6).

The synergy between MWCNT and MO nanoparticles in enhancing the electron transport process obtained at the GCE modified electrodes cannot be over emphasized. The conductive nature of the MO nanopartilses and the MWCNTs due to its facile electronic nature, plus the ionic interaction between the MO nanoparticles and MWCNTs are some of the factors responsible for this significant electron transport at the GCE-MWCNT-MO modified electrodes. Similarly, the large surface area created by the porous MWCNT on the electrode for free flow of electrolytes and charges between the base electrode and the electroactive species at the electrode surface is also another important factor for the great feat at the GCE- MWCNT-MO electrode. Similar results have been reported for modified electrodes in literature [57$60]$. The peak-to-peak potential separation $(\Delta \mathrm{Ep})$ for the three GCEMWCNT- MO electrodes is $\geqslant 100 \mathrm{mV}$, which is greater than the theoretical $59.8 \mathrm{mV}$ expected for a fast one-electron transport. Also, the ratios of the anodic to the cathodic peak current response (Ipa/Ipc) for GCE-MWCNT-NiO electrode is pproximately unity, indicative of reversible electrochemical process, while that of GCE-MWCNT-ZnO
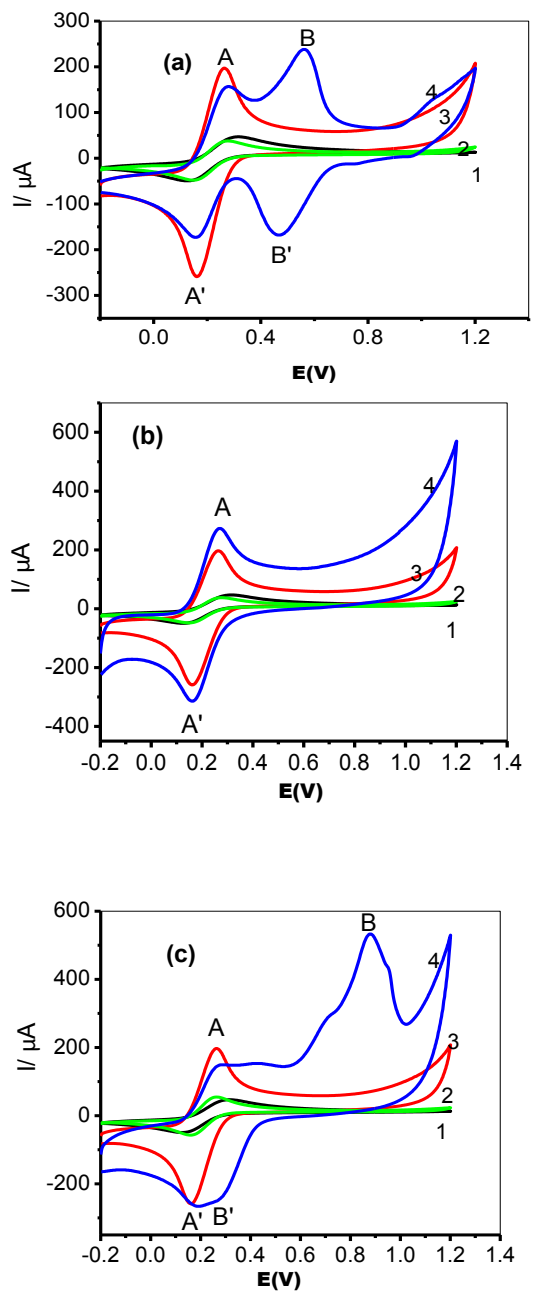

Figure 6: Cyclic Voltammograms of (1) GCE-MWCNT-MO, (2) GCE-MWCNT, (3) GCE- MO and (4) GCE in $\left.5 \mathrm{mM} \mathrm{Fe}(\mathrm{CN})_{6}\right]^{4-} /\left[\mathrm{Fe}(\mathrm{CN})_{6}\right]^{3-}$ solution prepared in $0.1 \mathrm{M}$ PBS at scan rate $25 \mathrm{mVs}^{-1}$. (MO: (a) $\mathrm{NiO}$, (b) $\mathrm{Fe}_{3} \mathrm{O}_{4}$, and (c) $\mathrm{ZnO}$ nanoparticles). and GCE-MWCNT- $\mathrm{Fe}_{3} \mathrm{O}_{4}$ are less than unity suggesting a quasireversible electron transfer process at these electrodes. Using the Randles-Sevcik equation below:

\section{$\mathrm{I}_{\mathrm{p}=}\left(2.99 \times 10^{5}\right) \alpha^{0.5} \mathrm{n}^{1.5} \mathrm{ACD}^{0.5} v^{0.5}$}

Where $\mathrm{n}$ is the number of electron transfer, $\alpha$ is the electron transfer coefficient, $\mathrm{A}$ is the electroactive surface area, $\mathrm{C}$ is bulk concentration (5 $\mathrm{mM})$ of $\left.\mathrm{Fe}(\mathrm{CN})_{6}\right]^{4-} /\left[\mathrm{Fe}(\mathrm{CN})_{6}\right]^{3-}$ and $\mathrm{D}$ is the diffusion coefficient. The electroactive surface area for the electrodes GCE-MWCNT- NiO, GCEMWCNT-ZnO and GCE-MWCNT- $\mathrm{Fe}_{3} \mathrm{O}_{4}$ were calculated to be 1.18 , 1.50 and $0.5 \mathrm{~cm}^{2}$ respectively. Therefore, the anodic current response (in current density) of each electrode in $\left.\mathrm{Fe}(\mathrm{CN})_{6}\right]^{4-} /\left[\mathrm{Fe}(\mathrm{CN})_{6}\right]^{3-}$ redox probe follows the order: GCE-MWCNT- $\mathrm{Fe}_{3} \mathrm{O}_{4}\left(1800 \mu \mathrm{Acm}^{-2}\right)>\mathrm{GCE}-$ MWCNT-ZnO $\left(366.7 \mu \mathrm{Acm}^{-2}\right)>$ GCE-MWCNT-NiO $\left(211.9 \mu \mathrm{Acm}^{-2}\right)$. Therefore GCE-MWCNT- $\mathrm{Fe}_{3} \mathrm{O}_{4}$ has demonstrated the best electron transport properties with current density approximately 5 and 9 times current produced at GCE-MWCNT-ZnO and GCE-MWCNT$\mathrm{NiO}$ electrodes respectively. This could be attributed to the presence of four (4) oxygen atoms with lone pair of electrons in $\mathrm{Fe}_{3} \mathrm{O}_{4}$ thereby contributing to the net electron cloud and electron transport process at the GCE-MWCNT- $\mathrm{Fe}_{3} \mathrm{O}_{4}$ electrode as compared with $\mathrm{NiO}$ and $\mathrm{ZnO}$ modified electrodes with one oxygen atom each.

The scan rate study (scan rate, $25-1000 \mathrm{mVs}^{-1}$ ) of the GCE-MWCNT$\mathrm{MO}$ electrode was carried out in $\left.5 \mathrm{mM} \mathrm{Fe}(\mathrm{CN})_{6}\right]^{4-} /\left[\mathrm{Fe}(\mathrm{CN})_{6}\right]^{3-}$ solution prepared in $0.1 \mathrm{M}$ PBS ( $\mathrm{pH} 7$ ) using cyclic voltammetry experiment. Both anodic current (Ipa) and cathodic current (Ipc) increase with increase in scan rates (25 to $1000 \mathrm{mVs}^{-1}$ ) (Figure 7).

The plot of the anodic peak currents (Ipa) varies linearly with square root of scan rate and the regression equation for the different electrodes is given below.

$$
\begin{aligned}
& I_{p}(\mu \mathrm{A})=8 \times 10^{-4} \mathrm{v}^{1 / 2}-3 \times 10^{-5} ; \mathrm{r}^{2}=0.9931(\text { GCE-MWCNT-NiO) } \\
& \mathrm{I}_{\mathrm{p}}(\mu \mathrm{A})=2.1 \times 10^{-3} \mathrm{v}^{1 / 2}-5 \times 10^{-4} ; \mathrm{r}^{2}=0.9671(\mathrm{GCE}-\mathrm{MWCNT}-\mathrm{ZnO}) \\
& \mathrm{I}_{\mathrm{p}}(\mu \mathrm{A})=5.2 \times 10^{-3} \mathrm{v}^{1 / 2}-6 \times 10^{-4} ; \mathrm{r}^{2}=0.9980\left(\mathrm{GCE}-\mathrm{MWCNT}-\mathrm{Fe}_{3} \mathrm{O}_{4}\right)
\end{aligned}
$$

The apparent charge transfer rate constant $(\mathrm{ks})$ and the charge transfer coefficient $(\alpha)$ of a surface-confined redox couple can be evaluated from the cyclic voltammetric experiments by using the variation of anodic and cathodic peak potentials with logarithm of scan rate. The Epa shifted to more positive values with increasing the scan rate $(v)$. The transfer coefficient (i.e., $\alpha$ ) and the number of electrons involved in the rate-determining step can be evaluated. Based on the slope of Epa versus $\log (v),(1-\alpha) n \alpha$ was calculated to be $0.74,0.34$ and 0.33 for electrodes GCE-MWCNT-NiO, GCE-MWCNT-ZnO and GCE-MWCNT- $\mathrm{Fe}_{3} \mathrm{O}_{4}$ respectively. The values of ks were evaluated to be $0.12,0.17$ and $0.15 \mathrm{cms}^{-1}$ for electrodes GCE- MWCNT-NiO, GCEMWCNT-ZnO and GCE-MWCNT- $\mathrm{Fe}_{3} \mathrm{O}_{4}$ respectively using equation (2).

$\log k s=\alpha \log (1-\alpha)+(1-\alpha) \log \alpha-\log (\mathrm{RT} / \mathrm{nFn})-\alpha(1-\alpha)$ $\mathrm{nFE} / 2.3 \mathrm{RT}$

Furthermore, from the slope of the linear plot of $I$ vs. $v$, the surface concentration of the electroactive species $(\Gamma)$ can be estimated according to the following equation.

$$
i_{p}=\frac{n^{2} F^{2} A \Gamma v}{4 R T}
$$

Where $(\Gamma)$ is the surface coverage, $A$ is the electrode surface area, $\mathrm{F}$ is the Faraday constant. The calculated surface coverage was 5.9, 6.7 and $2.2 \mathrm{nmol} / \mathrm{cm}^{2}$ for GCE-MWCNT-NiO, GCE-MWCNT-ZnO and GCE-MWCNT- $\mathrm{Fe}_{3} \mathrm{O}_{4}$ respectively. It should be pointed out that the 


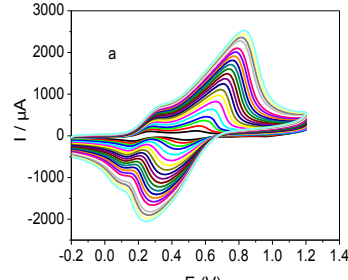

$E(V)$

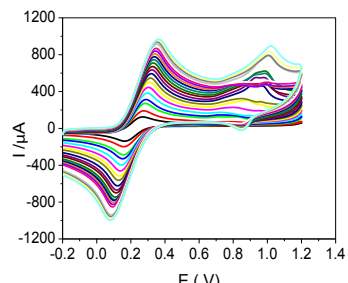

$\mathrm{E}(\mathrm{V})$

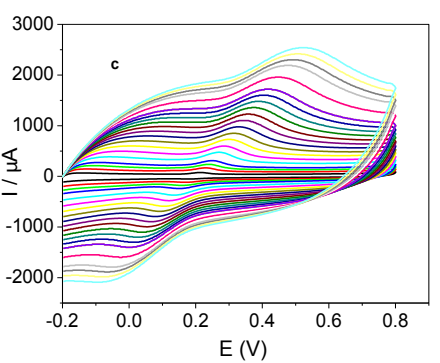

Figure 7: Cyclic Voltammograms obtained for (a) GCE-MWCNT-NiO, (b) GCEMWCNT-ZnO and (c) GCE-MWCNT-Fe $\mathrm{O}_{4}$ in $\left.5 \mathrm{mM} \mathrm{Fe}(\mathrm{CN})_{6}\right]^{4-} /\left[\mathrm{Fe}(\mathrm{CN})_{6}\right]^{3-}$ solution prepared in $0.1 \mathrm{M}$ PBS ( scan rate: $25-1000 \mathrm{mVs}^{-1}$; inner to outer).
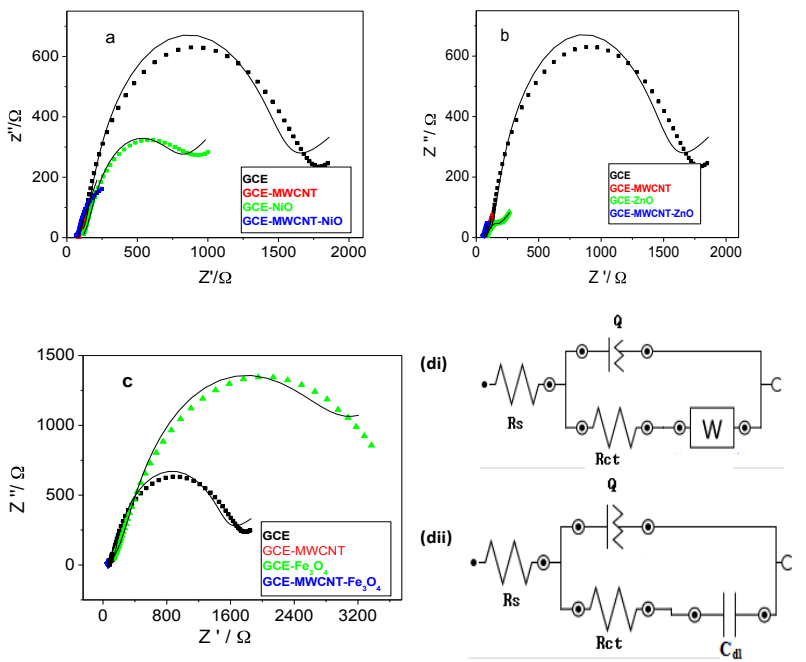

Figure 8: Typical Nyquist plots obtained for the electrodes in $5 \mathrm{mM}\left[\mathrm{Fe}(\mathrm{CN})_{6}\right]^{4-}$ $\left[\mathrm{Fe}(\mathrm{CN})_{6}\right]^{3-}$ solution (PBS pH 7.0) at a fixed potential of $0.2 \mathrm{~V}(\mathrm{vs} . \mathrm{Ag} \mid \mathrm{AgCl}$ saturated $\mathrm{KCl}$ ). The data points are experimental while the solid lines in the spectra represent non-linear squares fits. (di and dii) Represents the circuit used in the fitting of the EIS data for bare GCE and GCE-MWCNT, GCEMWCNT-MO, and MO respectively.

calculated surface coverage is an efficient attribute (per cross section of the electrode) and does not reflect the actual amount of MWCNT-MO per area of exposed glassy carbon.

Electrochemical impedance spectroscopic (EIS) studies: EIS is a complex electrochemical process that gives insightful information about reaction at the electrode-electrolyte interface. The result obtained is presented in Nyquist plot (Figure 8), which includes a semi-circular portion corresponding to the electron-transfer-limited process and a linear part resulting from the diffusion process [61]. The diameter of the semicircle corresponds to the electron transfer resistance (Rct) of the redox probe at the electrode interface. A smaller Rct value implies that the probe has a higher interfacial electron transfer rate (Figure 8).

The Nyquist plots obtained from the impedance experiment (at fixed potential of $0.2 \mathrm{~V}$ vs $\mathrm{Ag} / \mathrm{AgCl}$, sat'd $\mathrm{KCl}$ ) and between $10 \mathrm{KHz}$ and $1 \mathrm{~Hz}$ are presented in Figures $8 \mathrm{a}-8 \mathrm{c}$, while the circuit model used in the fitting of the impedance data is represented in Figure $8 \mathrm{~d}$ ( $\mathrm{i}$ and ii). where circuit 8di represent the EIS data fitting for bare GCE and 8dii represent that of the $\mathrm{NiO}, \mathrm{ZnO}, \mathrm{Fe}_{3} \mathrm{O}_{4}$, MWCNT, MWCNT-NiO, MWCNT-ZnO and MWCNT- $\mathrm{Fe}_{3} \mathrm{O}_{4}$ modified GCE electrodes. In this circuit model, $R s$ is the solution resistance, $C d l$ represents the double layer capacitance, $\mathrm{Q}$ or $\mathrm{CPE}$ is the constant phase element, and Rct is the charge transfer resistance. The values obtained from the fitting of the raw impedance spectra with this circuit are presented in Table 1.

From the Rct values, the electron transport is faster for the GCEMWCNT-MO electrode compared to others. The bare GCE exhibited a larger semicircle with an Rct value of $1.572 \mathrm{k} \Omega$ when compared with MWCNT-ZnO, MWCNT-NiO and MWCNT- $\mathrm{Fe}_{3} \mathrm{O}_{4}$ modified GCE $(38.2,6.86$ and $5.26 \Omega)$ respectively, revealing the fast electron transfer at MWCNT-MO modified electrode. The rapid electron transfer at the nanocomposite can be ascribed to the excellent conductivity of MWCNT, which acts as a good electron conducting wire between $\mathrm{MO}$ and the electrode surface. The $n$ values are less than the ideal 1.0 expected from an ideal capacitive behaviour, thus suggesting pseudocapacitive properties for these electrodes.

\section{Electrooxidation of DA at the surface of the Electrodes}

Figure 9 shows the electrochemical response of dopamine at bare GCE, GCE-MWCNT, GCE-MO and GCE-MWCNT-MO electrodes in $0.1 \mathrm{M}$ phosphate buffer solution $(\mathrm{pH} 7.0)$. The $\mathrm{CV}$ evolution of electrodes in DA is typical for DA oxidation process where the anodic peak corresponds to dopaminoquinone (DA+) (Figure 10 and scheme 2 ) and the cathodic peak corresponds to reduction of dopaminoquinone to leucodopanoquinone [62]. The results showed that DA was oxidized with well-defined sharp DA oxidation peak at lower potentials and significantly enhanced DA oxidation current at the GCE-MWCNTMO electrodes compared with other electrodes investigated (Figure 9).

The oxidation peak potentials of DA on the GCE-MWCNTMO modified electrodes were at around $0.20 \mathrm{~V}$ vs. $\mathrm{Ag} / \mathrm{AgCl}$. On the other hand, the indistinguishable and broad peak at a bare GCE and GCE-MO electrodes indicate a slow electron transfer kinetic at the electrode. In addition, the enhanced DA currents at lower potential at the GCE-MWCNT-MO indicate that the modified electrode plays a catalytic effect on the oxidation of DA. The DA oxidation current at

\begin{tabular}{|c|c|c|c|c|}
\hline Electrodes & \multicolumn{4}{|c|}{ Electrochemical impedance spectroscopy data } \\
\hline & $\mathrm{R}_{\mathrm{s}}(\Omega)$ & $\mathrm{Q}\left(\times 10^{6} \mathrm{nF}\right)$ & $\mathrm{R}_{\mathrm{ct}}(\Omega)$ & $\mathrm{C}_{\mathrm{dl}}(\mathrm{u} \mathrm{F})$ \\
\hline GCE & $126.60(0.04)$ & $8.44(1.19)$ & $1237.00(0.44)$ & $2.13(2.25)$ \\
\hline GCE-NiO & $104.60(1.62)$ & $940.00(3.95)$ & $442.00(2.14)$ & $22.63(2.42)$ \\
\hline GCE-ZnO & $70.80(1.10)$ & $3200.00(1.38)$ & $38.20(3.34)$ & $83.30(4.94)$ \\
\hline GCE-Fe $\mathbf{O}_{4}$ & $55.80(8.93)$ & $334.00(9.50)$ & $1915.00(4.37)$ & $10.61(3.84)$ \\
\hline GCE-MWCNT-NiO & $66.60(2.17)$ & $1410.00(4.05)$ & $6.86(23.39)$ & $10.90(3.81)$ \\
\hline GCE-MWCNT-ZnO & $53.90(1.39)$ & $5800.00(1.89)$ & $5.33(13.23)$ & $4.06(30.17)$ \\
\hline GCE-MWCNT-Fe $\mathbf{O}_{\mathbf{4}}$ & $60.30(0.59)$ & $8270.00(1.99)$ & $5.26(8.75)$ & $18.12(17.60)$ \\
\hline GCE-MWCNT & $85.30(0.59)$ & $7770.00(5.94)$ & $73.10(7.551)$ & $1.73(7.71)$ \\
\hline
\end{tabular}

Table 1: Impedance data obtained for the bare GCE and the modified electrodes in $\left.5 \mathrm{mM} \mathrm{Fe}(\mathrm{CN})_{6}\right]^{4-} /\left[\mathrm{Fe}(\mathrm{CN})_{6}\right]^{3-}$ solution at $0.2 \mathrm{~V}(\mathrm{vs}$. $\mathrm{Ag} / \mathrm{AgCl}$ saturated $\mathrm{KCl})$. All values were obtained from the fitted impedance spectra. The values in parentheses are percent errors of data fitting. 

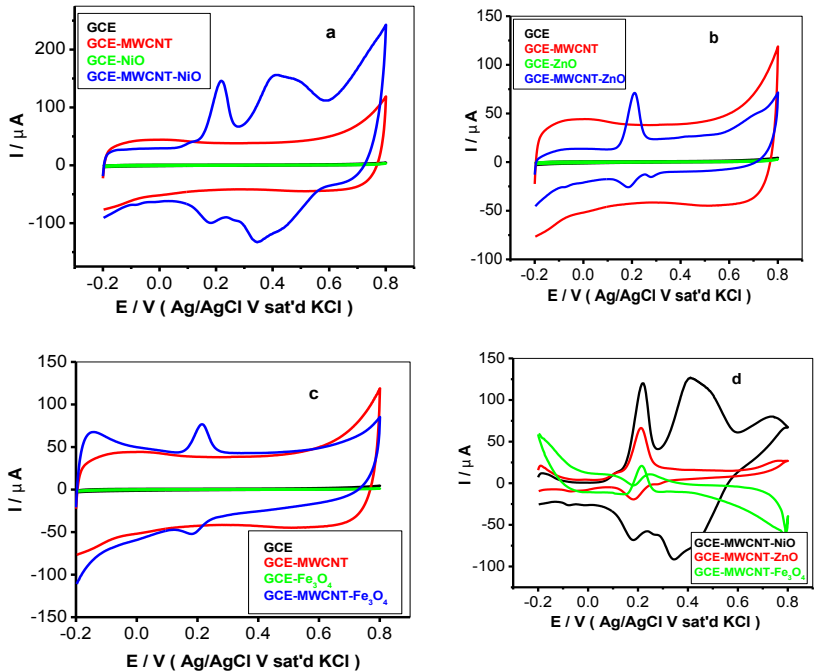

Figure 9: Cyclic voltammograms of $1 \times 10^{-4} \mathrm{M}$ DA on different electrodes (a) GCE-MWCNT-NiO, (b) GCE-MWCNT-ZnO and (c) GCE-MWCNT-Fe $\mathrm{O}_{4}$ and (d) background subtracted CVs.
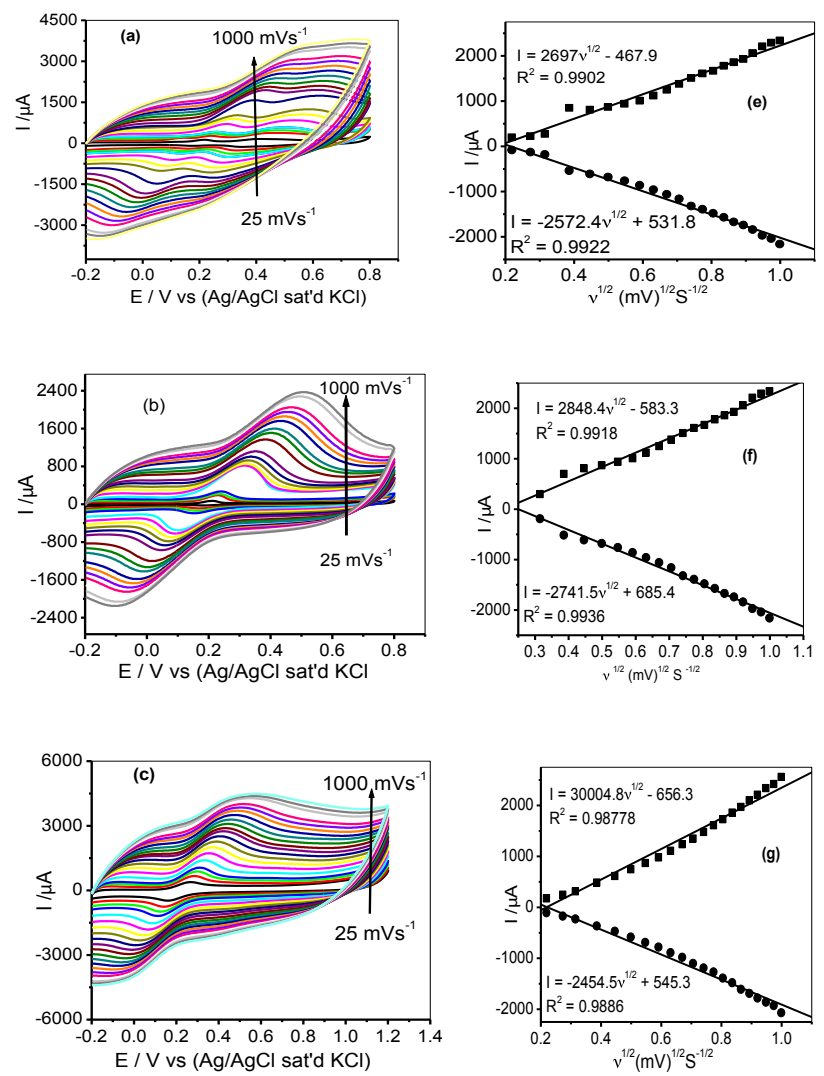

Figure 10: Cyclic voltammograms scan rate study of modified electrodes (a) GCE-MWCNT- NiO, (b) GCE-MWCNT-ZnO and (c) GCE-MWCNT-Fe $\mathrm{O}_{4}$ in 1 $\times 10^{-4} \mathrm{M}$ DA at various scan rates: $25-1000 \mathrm{mVs}^{-1}$ (e-g are the linear plots of current versus square root of scan rate for GCE-MWCNT-NiO, GCE-MWCNT$\mathrm{ZnO}$ and GCE-MWCNT- $\mathrm{Fe}_{3} \mathrm{O}_{4}$ respectively.

the GCE-MWCNT-MO electrodes follow the order: GCE-MWCNT$\mathrm{NiO}(145 \mu \mathrm{A})>$ GCE-MWCNT-ZnO $(76 \mu \mathrm{A})$ and GCE-MWCNT-<smiles>C#CCNCCC1=CC(=O)C(=O)C=C1</smiles>

Scheme 2: DA electrochemical oxidation at modified GCE-MWCNT-MO electrodes.

$\mathrm{Fe}_{3} \mathrm{O}_{4}(72 \mu \mathrm{A})$. In terms of current density, the DA oxidation current at the electrode follows the order: GCE-MWCNT-NiO $\left(1557 \mu \mathrm{Acm}^{-2}\right)$ $>$ GCE-MWCNT-ZnO $\left(1085.7 \mu \mathrm{Acm}^{-2}\right)$ and > GCE-MWCNT-Fe3O4 $\left(1028.6 \mu \mathrm{Acm}^{-2}\right)$ thus suggesting GCE-MWCNT-NiO electrode as the best electrode for DA oxidation in this study. The higher DA oxidation current at these electrodes indicates that the MWCNT has provided large surface area for effective diffusion of more DA molecules in and out of the electrode surface for maximum electrocatalytic oxidation by the MO nanoparticles compared with the bare GCE and other electrodes investigated. Similar results have been reported for DA oxidation on modified electrodes [63-65].

\section{Effect of varying scan rate}

Cyclic voltammetry experiments were carried out with the GCE-MWCNT-MO to establish the impact of scan rate at constant concentration $\left(10^{-4} \mathrm{M}\right)$ of dopamine in $\mathrm{pH}$ 7.0 PBS solutions. In all cases, we observed a shift in potential with increase in scan rate (Figure 10). From the Randles-Sev ${ }^{2}$ cik equation for an anodic oxidation process Equation (1), the plot of the peak currents (Ip) against the square root of scan rate $\left(v^{1 / 2}\right)$ (Figure 10) for scan rate ranging from 25 to $1000 \mathrm{mVs}^{-2}$, gave a linear relationship with equations;

$$
\begin{aligned}
& I_{p a}=2697.1 \mathrm{v}^{1 / 2}-467.92 ; R^{2}=0.992, I_{p a}=-2572.4 \mathrm{v}^{1 / 2}+551.82 ; R^{2}=0.991 \\
& I_{p a}=2719.2 \mathrm{v}^{1 / 2}-487.96 ; R^{2}=0.9931, I_{p a}=-2574.4 \mathrm{v}^{1 / 2}+553.96 ; R^{2}=0.9931 \\
& I_{p a}=3004.8 \mathrm{v}^{1 / 2}-656.35 ; R^{2}=0.9931, I_{p a}=-2454.5 \mathrm{v}^{1 / 2}+545.33 ; R^{2}=0.9931
\end{aligned}
$$

(Figure 10) and approximately zero intercept, confirming a diffusioncontrolled process but with some levels of adsorbed reaction intermediates. The linear relationship of the plot confirmed that the nano composites were electroactive, conducting and confined to the surface. This was further confirmed by the plots of log of peak current against log of scan rate (graphs not shown) which gave a slope of 1 as expected for the electrochemistry of surface-absorbed species as shown by relationship below [66].

$$
\begin{array}{lll}
\text { GCE-MWCNT-NiO: } & \mathrm{I}_{\mathrm{pa}}=1.0544 \log \mathrm{v}+2.5007 ; & \mathrm{R}^{2}=0.9907 \\
\text { GCE-MWCNT-ZnO: } & \mathrm{I}_{\mathrm{pa}}=1.0827 \log \mathrm{v}+2.7936 ; & \mathrm{R}^{2}=0.9651 \\
\text { GCE-MWCNT- } \mathrm{Fe}_{3} \mathrm{O}_{4}: & \mathrm{I}_{\mathrm{pa}}=1.0721 \log \mathrm{v}+2.7727 ; & \mathrm{R}^{2}=0.9987
\end{array}
$$

The charge transfer coefficient ( $\alpha$ ) for the reaction can be evaluated from cyclic voltammetric experiments by using the variation of anodic and cathodic peak potentials with logarithm of scan rate. Based on the slope of Epa with $\log (v),(1-\alpha) n \alpha$ was calculated to be $0.86,0.84$ and 0.85 for electrodes GCE-MWCNT-NiO, GCE-MWCNT-ZnO and GCE-MWCNT- $\mathrm{Fe}_{3} \mathrm{O}_{4}$ respectively. In order to get information on the rate determining step, The peak potential, Ep, is proportional to $\log v$ (graph not shown). The slopes of $E \mathrm{p} v s . \log v$ for the different electrodes were $0.226,0.190$, and $0.196 \mathrm{~V}$ for electrodes GCE-MWCNT-NiO, 
GCE- MWCNT-ZnO and GCE-MWCNT- $\mathrm{Fe}_{3} \mathrm{O}_{4}$ respectively. The tafel slopes may be estimated according to the equation (4) for the totally irreversible diffusion controlled process [67]. So, the respective values of $b$ for these electrodes were obtained as $0.452,0.380$ and 0.392 $\mathrm{Vdec}^{-1}$. These values are higher than the theoretical $0.118 \mathrm{~V} \mathrm{dec}^{-1}$ for a one-electron process involved in the rate-determining step. Therefore the high tafel values suggest adsorption of dopamine or its reaction intermediate at the electrode surface since high tafel values have been attributed to the adsorption of reactants or intermediates on the electrode surfaces and/or reactions occurring within a porous electrode structure [68]. Adsorption process at the electrode can be linked with the porous CNT layer [69].

$$
E_{p}=\left(\frac{b}{2}\right) \log v+\text { constant }
$$

If a was assumed equal to $0.5, n a$ was 1.7 (approximately 2 ) for all the electrodes indicating that the redox reaction of DA on the GCE electrodes GCE-MWCNT-NiO, GCE-MWCNT- ZnO and GCEMWCNT- $\mathrm{Fe}_{3} \mathrm{O}_{4}$ was two protons coupled two electrons process. Also, the electron transfer rate constant for the GCE-MWCNT-MO electrode can be determined using Equation 2 above, and assuming (1- $\alpha) n a=0.56$ [67] $v$ is the sweep rate and all other symbols having their conventional meanings. The value of ks was evaluated to be equal to $0.65,0.81$ and $0.05 \mathrm{~cm} \mathrm{~s}^{-1}$ for electrodes GCE-MWCNT-NiO, GCEMWCNT-ZnO and GCE-MWCNT- $\mathrm{Fe}_{3} \mathrm{O}_{4}$ respectively. According to the kinetics of electron process, when the rate constant is larger than $10^{-2} \mathrm{~cm} / \mathrm{s}$, the electron transfer process is very fast, and the electrode reaction is reversible, and when $10^{-4}<\mathrm{ks}<10^{-2} \mathrm{~cm} / \mathrm{s}$, the electrode reaction is a quasireversible process.

So the electrode reaction of DA on the proposed electrodes is reversible process.

The stability of modified GCE towards oxidation of DA was checked by repetitive scanning ( 20 scans). The results show that the modified electrode has a good stability in aqueous solution after repeated twenty cyclic voltammogram of modified GCE-MWCNTMO in $1 \times 10^{-4} \mathrm{M}$ of DA at $\mathrm{pH}=7.0$ phosphate buffer solution between -0.2 to $0.8 \mathrm{~V}$ (scan rate: $25 \mathrm{mVs}^{-1}$ ) (graph not shown). The anodic peak current decrease for about 7, 8 and $4 \%$ at electrodes GCE-MWCNT$\mathrm{NiO}, \mathrm{GCE}-\mathrm{MWCNT}-\mathrm{ZnO}$ and GCE-MWCNT- $\mathrm{Fe}_{3} \mathrm{O}_{4}$ respectively after twenty cyclic voltammogram in the supporting electrolyte. However, on rinsing the electrode in a fresh PBS ( $\mathrm{pH} 7.0)$ solution, the electrode surface was renewed and more than $95 \%$ of the initial catalytic current was obtained, indicating the electrochemical stability and reusability of the electrode after analysis. The electrode was also used for the analysis of DA after storage in a refrigerator for up to two weeks without a significant change in its response.

Impedance studies were also carried out to monitor the mechanism of the electron transfer process during the electrocatalytic oxidation of $10^{-4} \mathrm{M} \mathrm{DA}$ at fixed potential $0.2 \mathrm{~V}$ and frequencies between $10 \mathrm{kHz}$ and $1.0 \mathrm{~Hz}$. the impedance spectra (Nyquist plots) obtained for the electrodes are presented in Figure 11a, while Figure 11b shows the equivalent circuits used in the fitting of the impedance data. (Figure 11)

However the GCE-electrodes were successfully fitted with minimum error values especially for the Rct data using circuit model $\mathrm{RQ}(\mathrm{RC})$ (Figure 11). The charge transfer resistance Rct is lower at GCE MWCNT-MO compared with the bare GCE, GCE-MWCNT and GCE-MO. The finding further confirms the CV data and also indicates that the electron transfer process is faster at GCE-MWCNTMO electrodes with GCE-MWCNT-NiO > GCE-MWCNT-ZnO and >
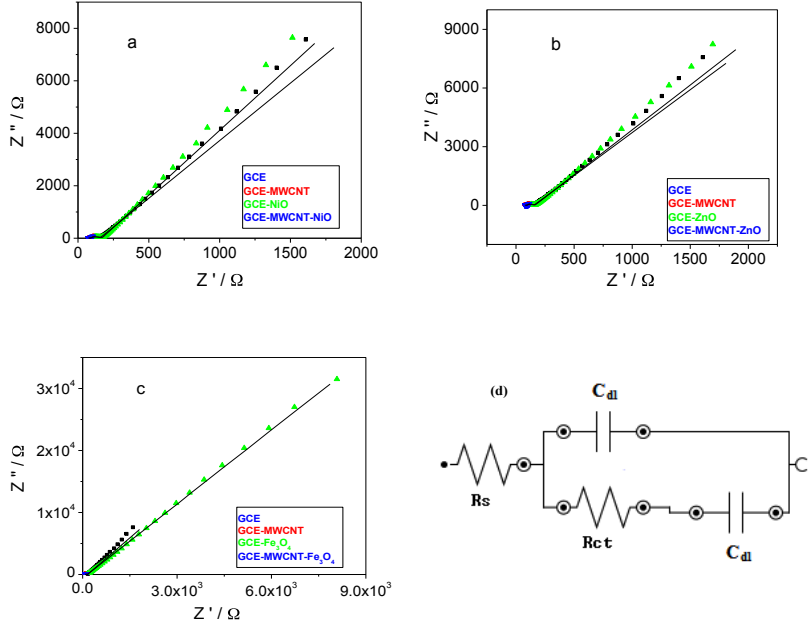

Figure 11: Typical Nyquist plots obtained for the electrodes in $1 \times 10^{-4} \mathrm{M} \mathrm{DA}$ solution (PBS $\mathrm{pH} 7.0$ ) at a fixed potential of $0.2 \mathrm{~V}$ (vs. $\mathrm{Ag} \mid \mathrm{AgCl}$, saturated $\mathrm{KCl}$ ). The data points are experimental while the solid lines in the spectra represent non-linear squares fits. (d) Represent the circuit used in the fitting of the EIS data in (a-c).

\begin{tabular}{|l|c|c|c|c|}
\hline \multirow{2}{*}{ Electrodes } & \multicolumn{4}{|c|}{ Electrochemical impedance spectroscopy data } \\
\hline GCE & Rs $(\Omega)$ & $\mathrm{Q}(\times 106 \mathrm{nF})$ & $\mathrm{Rct}(\Omega)$ & $\mathrm{Cdl}(\mathrm{u} \mathrm{F})$ \\
\hline GCE-MWCNT & $54.70(9.05)$ & $2.77(1.33)$ & $98.40(4.63)$ & $163.70(10.56)$ \\
\hline GCE-NiO & $80.40(0.50)$ & $307.00(3.25)$ & $8.50(7.77)$ & $78.50(15.72)$ \\
\hline GCE-ZnO & $62.60(8.53)$ & $2.65(1.31)$ & $104.80(4.72)$ & $152.30(10.72)$ \\
\hline GCE-Fe $\mathbf{3}_{\mathbf{4}} \mathbf{O}_{4}$ & $81.20(7.95)$ & $80.30(3.04)$ & $80.40(7.47)$ & $180.90(16.73)$ \\
\hline GCE-MWCNT-NiO & $134.60(3.18)$ & $80.30(3.04)$ & $319.00(2.586)$ & $8.66(3.54)$ \\
\hline GCE-MWCNT-ZnO & $80.10(0.47)$ & $350.00(3.80)$ & $9.50(7.18)$ & $63.00(14.82)$ \\
\hline GCE-MWCNT-Fe $\mathbf{O}_{\mathbf{4}}$ & $78.90(0.65)$ & $235.00(6.64)$ & $33.30(5.19)$ & $93.30(5.15)$ \\
\hline
\end{tabular}

Table 2: Impedance data obtained electrodes in $1 \times 10^{-4} \mathrm{M}$ DA solution in $\mathrm{pH} 7.0$ PBS (at $0.2 \mathrm{~V}$ vs. $\mathrm{Ag} / \mathrm{AgCl}$ saturated $\mathrm{KCl}$ ). The values in parentheses are percent errors of data fitting

GCE-MWCNT- $\mathrm{Fe}_{3} \mathrm{O}_{4}$ as shown in Table 2. This was achieved because of the presence of MWCNT on the electrode. The MWCNT creates a porous and large surface area that mediates the analyte/catalyst electrocatalytic process (Table 2).

\section{Electroanalysis of dopamine}

Since the proposed MWCNT-MO GCE electrodes have demonstrated favourable electrochemical response towards DA, they have been used for determination of DA. To improve the sensitivity of the developed sensors in detection of DA, square wave voltemmetry (SWV) technique has been used. Results showed that the electrochemical oxidation current is linearly proportional to its concentration in the range $4.0 \times 10^{-11} \mathrm{~mol} / \mathrm{L}$ to $6.25 \times 10^{-6} \mathrm{~mol} / \mathrm{L}$ for electrodes GCE-MWCNT-NiO, GCE-MWCNT-ZnO and GCEMWCNT- $\mathrm{Fe}_{3} \mathrm{O}_{4}$ respectively (Figure 12). The respective detection limit for the electrodes were calculated based on the relationship $\mathrm{LoD}=3.3$ $\delta / \mathrm{m}$ where $\delta$ is the relative standard deviation of the intercept of the $\mathrm{y}$-coordinates from the line of best fit, and $\mathrm{m}$ the slope of thesame line to be $7.99 \times 10^{-12}, 3.74 \times 10^{-7}$, and $1.389 \times 10^{-6} \mathrm{~mol} / \mathrm{L}=3$ ) for electrodes GCE-MWCNT-NiO, GCE-MWCNT-ZnO and GCE-MWCNT- $\mathrm{Fe}_{3} \mathrm{O}_{4}$ respectively. The nano molar limit of detection obtained for GCE- 
MWCNT-NiO compared favourably and even better that the limit of detection reported for other electrodes in literature (Table 3 and Figure 12).

\section{Interference study: Detection of DA in the presence of AA}

Figure 13 is the cyclic voltammetric responses of (a) bare GCE (b) GCE-MWCNT-ZnO, (c) GCE-MWCNT-NiO and (d) GCEMWCNT- $\mathrm{Fe}_{3} \mathrm{O}_{4}$ in $0.1 \mathrm{M} \mathrm{pH} 7.0 \mathrm{PBS}$ containing mixture of $10^{-2} \mathrm{M} \mathrm{AA}$, approximately 1000 times concentration of DA. On the bare electrode the detection of DA in the presence of AA was not successful (Figure 13a). That is, AA signal interferes with the DA signal thus no signal separation for the two analytes. (Figure 13).

However at the GCE-MWCNT-MO modified electrodes, AA signal which was initially observed at $0.05 \mathrm{~V}$ in the absence of DA remained at the same potential after the addition of DA, while the DA signal was

\begin{tabular}{|c|c|c|c|c|}
\hline Electrode material & Techniques & Interference & $\begin{array}{c}\text { Detection } \\
\text { Limit (molL-1) }\end{array}$ & References \\
\hline SWNT/Ppy,Surf.cov.bend & SWV & AA & $5.00 \times 10^{-6}$ & {$[60]$} \\
\hline MWCNT/B-CD modified & GCE SWV & AA & $6.70 \times 10^{-6}$ & {$[61]$} \\
\hline $\mathrm{Fe}_{3} \mathrm{O}_{4} /$ rGO/GO & SWV & AA & $1.20 \times 10^{-7}$ & {$[62]$} \\
\hline GCE/MWCNT-NiO & SWV & AA & $7.99 \times 10^{-12}$ & This work \\
\hline GCE/MWCNT-ZnO & SWV & AA & $3.74 \times 10^{-7}$ & This work \\
\hline GCE/MWCNT-Fe ${ }_{3} \mathrm{O}_{4}$ & SWV & AA & $1.39 \times 10^{-6}$ & This work \\
\hline
\end{tabular}

Table 3: Comparison of different electrochemical sensors for the determination of dopamine.
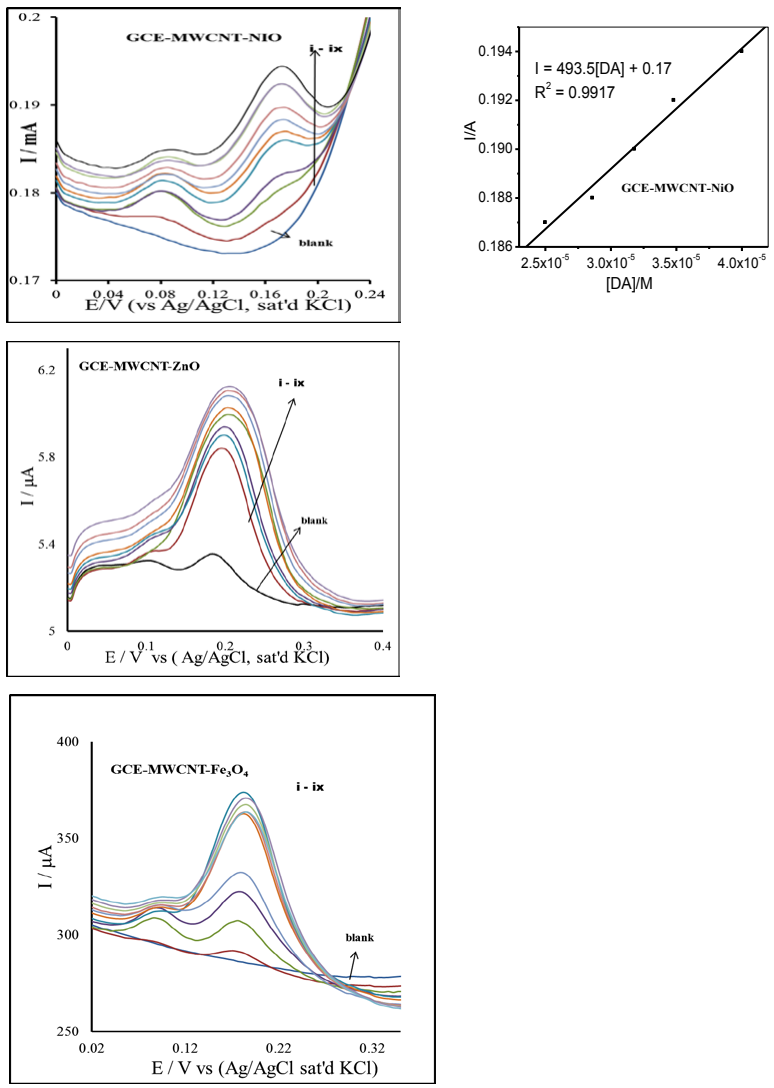

Figure 12: SWV of GCE-MWCNT-NiO, GCE-MWCNT-ZnO and GCEMWCNT- $\mathrm{Fe}_{3} \mathrm{O}_{4}$ in $1 \times 10^{-4} \mathrm{M}$ DA (inset is the graph of current vs concentration of DA).
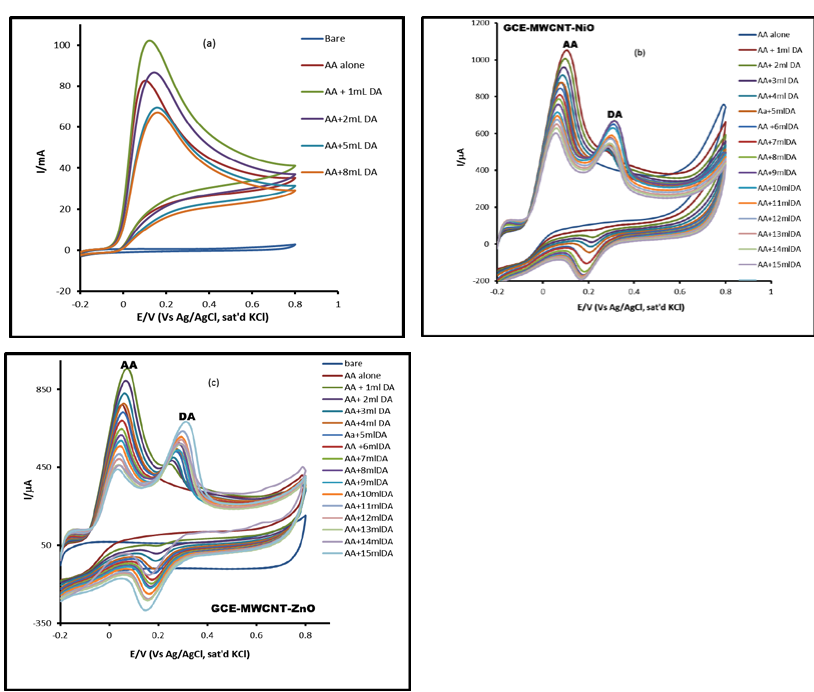

Figure 13: Cyclic voltammograms responses of: (a) bare GCE in PBS $(\mathrm{pH}$ 7.0), $10^{-2} \mathrm{M} \mathrm{AA}$ alone and $10^{-2} \mathrm{M} \mathrm{AA}+$ different volume of $10^{-4} \mathrm{M}$ DA solutions; (b) GCE-MWCNT-ZnO, and (c) GCE-MWCNT-NiO in (i) $0.1 \mathrm{M}$ pH 7.0 PBS (ii) $10^{-2} \mathrm{M} \mathrm{AA}$ alone, (iii) mixture of $9.09 \mathrm{mM} \mathrm{AA} / 9.09 \mu \mathrm{M} \mathrm{DA}$, (iv) mixture of 8.33 $\mathrm{mM}$ AA/16.7 $\mu \mathrm{M}$ DA (v) mixture of $7.69 \mathrm{mM} \mathrm{AA} / 23.0 \mathrm{DA} \mu \mathrm{M}$ (vi) $7.14 \mathrm{mM}$ $\mathrm{AA} / 28.6 \mu \mathrm{M}$ DA (vii) $6.67 \mathrm{mM}$ AA/33.0 $\mu \mathrm{M}$ DA (viii) $6.25 \mathrm{mM}$ AA/37.5 $\mu \mathrm{M}$ DA (ix) $5.88 \mathrm{mM} \mathrm{AA} / 41.2 \mu \mathrm{M}$ DA (x) $5.56 \mathrm{mM}$ AA/44.0 $\mu \mathrm{M}$ DA (xi) $5.2 \mathrm{mM}$ AA/47.0 $\mu \mathrm{M}$ DA and (xii) $5 \mathrm{mM}$ AA/50 $\mu \mathrm{M}$ DA concentrations.

observed at $0.25 \mathrm{~V}$. The simultaneous detection of AA and DA even at AA concentration $(9.09 \mathrm{mM})$ which is 1000 times as high as DA concentration $(9.09 \mu \mathrm{M})$ was successful at the GCE-MWCNT-MO electrodes with potential separation of about $170 \mathrm{mV}, 190 \mathrm{mV}$ and 150 $\mathrm{mV}$ observed at GCE-MWCNT-NiO, GCE-MWCNT-ZnO and GCEMWCNT- $\mathrm{Fe}_{3} \mathrm{O}_{4}$ electrodes respectively. The height and amplitude of the peak corresponding to DA signal increases as the concentration DA increases.

The simultaneous determination of DA in the presence of AA has also been carried out using more sensitive techniques such as differential pulse voltammetry (DPV) (Figure 14), square wave voltammetry (SWV) (Figure 15) and chronoamperometric (CA) techniques (Figure 16). A well resolved signal difference at large enough potential peak separation was observed for the modified electrodes using SWV and DPV respectively as compared to CV. For example using SWV, potential peak separation of about $200 \mathrm{mV}, 500$ $\mathrm{mV}$ and $250 \mathrm{mV}$ observed at GCE-MWCNT-NiO, GCE-MWCNT$\mathrm{ZnO}$ and GCE-MWCNT- $\mathrm{Fe}_{3} \mathrm{O}_{4}$ electrodes respectively, while DPV gave peak separation of $400 \mathrm{mV}, 300 \mathrm{mV}$ and $600 \mathrm{mV}$ observed at GCE-MWCNT-NiO, GCE-MWCNT-ZnO and GCE-MWCNT$\mathrm{Fe}_{3} \mathrm{O}_{4}$ electrodes respectively. Figure 16 presents the amperometric measurements recorded at an applied potential of $+0.20 \mathrm{~V}$ vs. $\mathrm{Ag} / \mathrm{AgCl}$ on MWCNT-NiO, GCE-MWCNT-ZnO and GCE-MWCNT-Fe ${ }_{3} \mathrm{O}_{4}$ modified electrodes by continuous addition of $1 \mathrm{ml} \mathrm{DA}$ and $1 \mathrm{ml} \mathrm{AA}$ (approx. 1000x DA concentration) respectively. The DA response was determined before and after 50s injection of AA into the DA solution. From the result obtained, there is no significant decrease in DA current response after addition of different concentration of ascorbic acid (AA) indicating that AA signal did not interfere with DA detection on the developed GCE-MWCNT-MO modified electrodes. GCE-MWCNT$\mathrm{NiO}$ and GCE-MWCNT-ZnO gave comparable DA recovery current compare with GCE-MWCNT- $\mathrm{Fe}_{3} \mathrm{O}_{4}$ (Figures 14-16). 

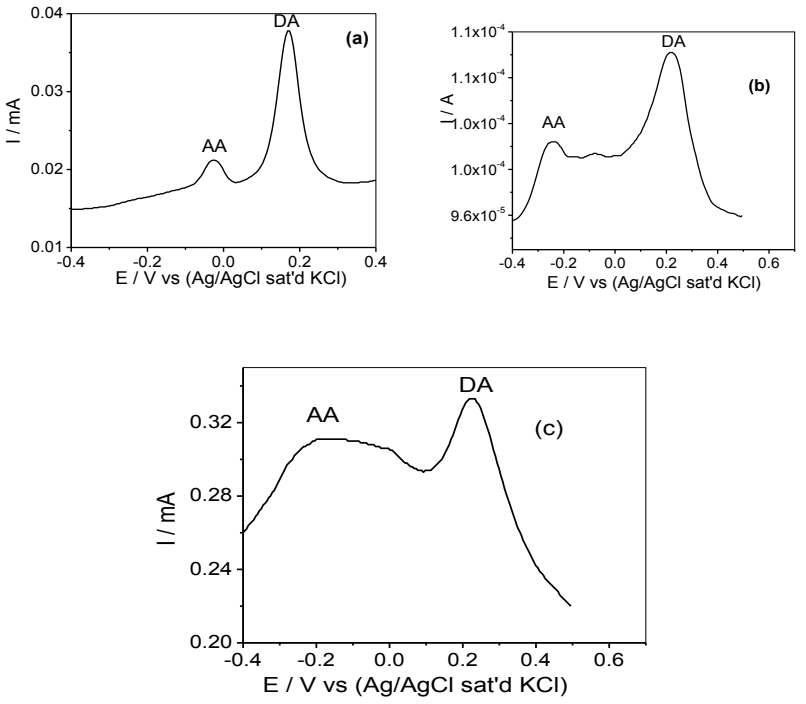

Figure 14: DPV profiles of (a) GCE-MWCNT-NiO, (b) GCE-MWCNT-ZnO and (c) GCE- MWCNT- $\mathrm{Fe}_{3} \mathrm{O}_{4}$ in $\mathrm{pH} 7.0$ PBS containing $10^{-2} \mathrm{M}$ AA and $10^{-4} \mathrm{M} \mathrm{DA}$ solutions respectively.
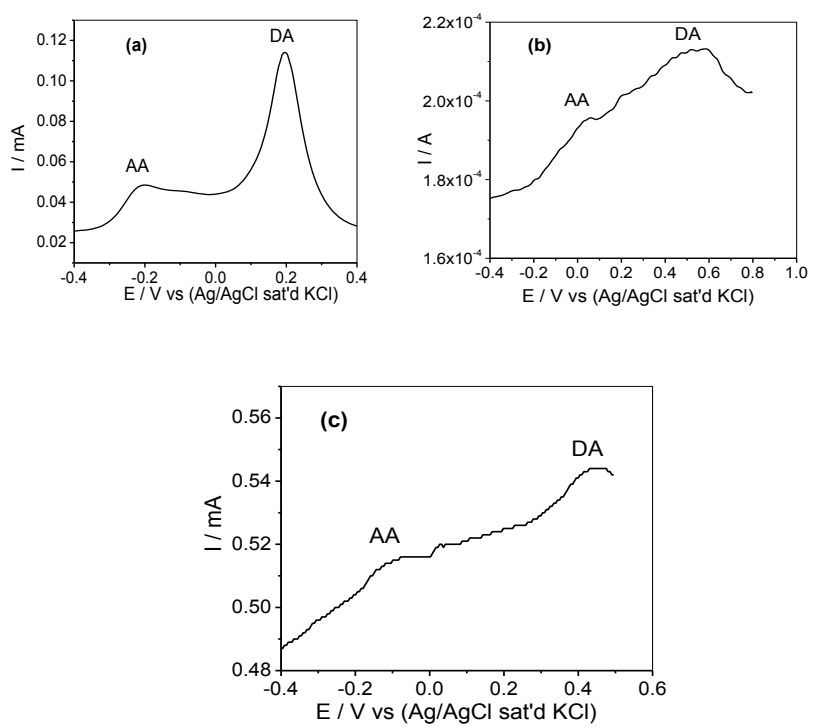

Figure 15: SWV profiles of (a) GCE-MWCNT-NiO, (b) GCE-MWCNT-ZnO and (c) GCE-MWCNT- $\mathrm{Fe}_{3} \mathrm{O}_{4}$ in $\mathrm{pH} 7.0$ PBS containing $10^{-2} \mathrm{M} \mathrm{AA}$ and $10^{-4} \mathrm{M}$ DA solutions respectively.

Analytical performance of the proposed sensors for determination of DA in pharmaceutical sample

The proposed sensors were tested for determination of DA in dopamine hydrochloride injection samples. The SWV method was used for the determination of DA in Pharmaceutical samples. The samples were prepared and adjusted to $3.5 \times 10^{-4} \mathrm{M}$ DA in $0.1 \mathrm{M}$ PBS ( $\mathrm{pH} 7.0$ ), by dilution of DA ampoule contents $(2.5 \mathrm{ml}$ of $40 \mathrm{mg} / \mathrm{ml} \mathrm{DA}$ hydrochloride injection solution). The standard addition experiment was carried out by addition of different concentrations of DA to the drug sample and its DA concentration evaluated using SWV. The obtained equations for the plot of peak current versus concentration of
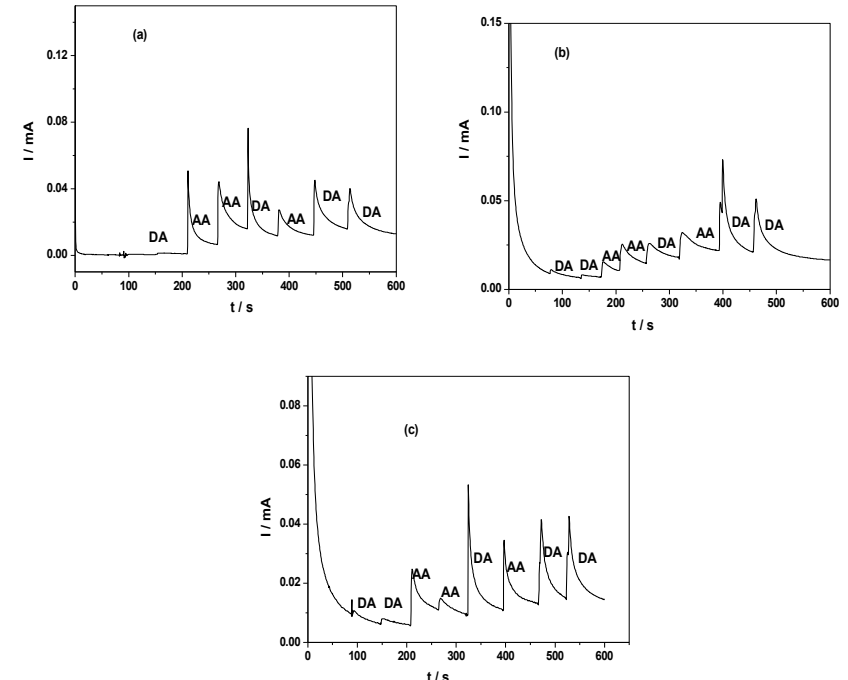

Figure 16: Chronoamperometric curves of (a) GCE-MWCNT-NiO, (b) GCEMWCNT-ZnO and (c) GCE-MWCNT- $\mathrm{Fe}_{3} \mathrm{O}_{4}$ in pH 7.0 PBS containing $10^{-4} \mathrm{M}$ $\mathrm{DA}$ and different concentration of $\mathrm{AA}$ (approx. 1000 times DA concentration).

\begin{tabular}{|c|c|c|c|c|}
\hline Electrode & $\begin{array}{c}\text { Added } \\
\text { (mg/ml) }\end{array}$ & $\begin{array}{c}\text { Detected } \\
\text { (mg/ml) }\end{array}$ & $\begin{array}{c}\text { Recovery } \\
(\mathbf{\%})\end{array}$ & RSD \% \\
\hline GCE-MWCNT-NiO & 40 & 44.9 & 112.4 & 0.1 \\
\hline GCE-MWCNT-ZnO & 40 & 39.1 & 97.8 & 0.13 \\
\hline GCE-MWCNT-Fe $\mathbf{O}_{\mathbf{4}}$ & 40 & 36.1 & 90.3 & 0.3 \\
\hline
\end{tabular}

Table 4: Results of detection of DA in dopamine hydrochloride injection $(n=5)$.

DA (graph not shown) are:

The analytical results obtained are presented in Table 4 . The result clearly indicates that dopamine can be reliably assayed from its drug using the proposed GCE-MWCNT-MO sensor.

\section{Conclusion}

This work describes the electron transport and electrocatalytic properties of chemically-synthesized metal oxide nanoparticles $\left(\mathrm{NiO}, \mathrm{ZnO}\right.$ and $\mathrm{Fe}_{3} \mathrm{O}_{4}$ ) supported on multi-walled carbon nanotubes (MWCNT) platforms on GCE. It is shown that the GCE-MWCNT$\mathrm{MO}$ nanocomposite modified electrode gave better electron transport as well as better DA response compared with other electrodes investigated. GCE-MWCNT-NiO electrode has proven to be the best electrode in terms of DA oxidation current and nano molar limit of detection. DA and ascorbic acid (AA) signal were well resolved using SWV and DPV techniques compared to CV techniques, with DPV giving the best peak separation of $400 \mathrm{mV}, 300 \mathrm{mV}$ and $600 \mathrm{mV}$ at GCE-MWCNT-NiO, GCE-MWCNT-ZnO and GCE-MWCNT- $\mathrm{Fe}_{3} \mathrm{O}_{4}$ electrodes respectively. Electrocatalysis of DA on the GCE-MWCNTMO electrodes was through diffusion and surface-confined electrode process. The study also showed that the GCE/MWCNT/NiO modified electrode can be successfully used for the assay of dopamine in DA real life samples.

\section{Acknowledgements}

This project was supported by the North-West University (Mafikeng Campus), Material Science Innovation and Modelling (MaSIM) Focus Area, Faculty of Agriculture, Science and Technology, North-West University (Mafikeng Campus). 
Citation: Fayemi OE, Adekunle AS, Ebenso EE (2015) Metal Oxide Nanoparticles / Multi-walled Carbon Nanotube Nanocomposite Modified Electrode for the Detection of Dopamine: Comparative Electrochemical Study. J Biosens Bioelectron 6: 190. doi:10.4172/2155-6210.1000190

Page 13 of 14

ASA thanks the North-West University for post-doctoral fellowship and Obafemi Awolowo University, Nigeria for the research leave visit. EEE acknowledges the National Research Foundation of South Africa for Incentive funding for Rated Researchers.

\section{References}

1. Hyman SE, Malenka RC (2001) Addiction and the brain: The neurobiology of compulsion and its persistence. Nat Rev Neurosci 2: 695-703.

2. Nikolaus S, Antke C, Müller HW (2009) In vivo imaging of synaptic function in the central nervous system: II. Mental and affective disorders. Behav Brain Res 204: 32-66.

3. Sardar AM, Czudek C, Reynolds GP (1996) Dopamine deficits in the brain The neurochemical basis of parkinsonian symptoms in AIDS. Neuroreport 7 : 910-912.

4. Perry KW, Fuller RW (1992) Effect of fluoxetine on serotonin and dopamine concentration in microdialysis fluid from rat striatum. Life Sci 50: 1683-1690.

5. Parsons LH, Justice Jr JB, (1993) Perfusate serotonin increases extracellular dopamine in the nucleus accumbens as measured by in vivo microdialysis. Brain Research 606: 195-199.

6. Yoshitake T, Kehr J, Todoroki K, Nohta H, Yamaguchi M (2006) Derivatization chemistries for determination of serotonin, norepinephrine and dopamine in brain microdialysis samples by liquid chromatography with fluorescence detection. Biomedical Chromatography 20: 267-281.

7. Shafi N, Midgley JM, Watson DG, Smail GA, Strang R, et al. (1989) Analysis of biogenic amines in the brain of the American cockroach (Periplaneta Americana) by gas chromatography-negative ion chemical ionisation mass spectrometry. J. Chromatography B 490: 9-19.

8. Salem FB (1987) Spectrophotometric and titrimetric determination of catecholamines. Talanta 34: 810-812.

9. Zhang L, Teshima N, Hasebe T, Kurihara M, Kawashima T (1999) Flowinjection determination of trace amounts of dopamine by chemiluminescence detection. Talanta 50: 677-683.

10. Wu K, Fei J, Hu S (2003) Simultaneous determination of dopamine and serotonin on a glassy carbon electrode coated with a film of carbon nanotubes. Anal Biochem 318: 100-106.

11. Torabi R, Compton RG (2007) A simple electroanalytical methodology for the simultaneous determination of dopamine, serotonin and ascorbic acid using an unmodified edge plane pyrolytic graphite electrode. Anal and Bioanal Chem 387: 2793-2800.

12. Sun CL, Lee HH, Yang JM, Wu CC (2011) The simultaneous electrochemical detection of ascorbic acid, dopamine, and uric acid using graphene/sizeselected Pt nanocomposites. Biosens Bioelectron 26: 3450-3455.

13. Adekunle AS, Ozoemena KI, Agboola BO (2013) MWCNTs/metal (Ni, Co, Fe) oxide nanocomposite as potential material for supercapacitors application in acidic and neutral media. J Electrochem 17: 1311-1320.

14. Selvaraju T, Ramaraj R (2003) Simultaneous determination of ascorbic acid, dopamine and serotonin at poly(phenosafranine) modified electrode. Electrochem. Communic 5: 667-671.

15. Jiang X, Lin X, (2005) Overoxidized polypyrrole film directed DNA immobilization for construction of electrochemical micro-biosensors and simultaneous determination of serotonin and dopamine. Analytica Chimica Acta 537: 145-151.

16. Habibi B, Pournaghi-Azar MH (2010) Simultaneous determination of ascorbic acid, dopamine and uric acid by use of a MWCNT modified carbon-ceramic electrode and differential pulse voltammetry. Electrochim. Acta 55: 5492-5498.

17. Arvand M, Niazi A, Motaghed Mazhabi R, Biparva P (2012) Direct electrochemistry of adenine on multiwalled carbon nanotube-ionic liquid composite film modified carbon paste electrode and its determination in DNA. J. Mol. Liq 173: 1-7.

18. Prabakar SJ, Sakthivel C, Narayanan SS (2011) Hg(II) immobilized MWCNT graphite electrode for the anodic stripping voltammetric determination of lead and cadmium. Talanta 85: 290-297.

19. Esmaeilifar A, Yazdanpour M, Zamir SR, Eikani MH (2011) Hydrotherma synthesis of Pt/MWCNTs nanocomposite electrocatalysts for proton exchange membrane fuel cell systems. Int J Hydrogen Energy 36: 5500-5511.

20. Zhao Y, E YF, Fan LZ, Qu YF, Yang SH (2007) A new route for the electrodeposition of platinum-nickel alloy nanoparticles on multi-walled carbon nanotubes. Electrochim Acta 52: 5873-5878.

21. Periasamy AP, Ho YH, Chen SM (2011) Multiwalled carbon nanotubes dispersed in carminic acid for the development of catalase based biosenso for selective amperometric determination of $\mathrm{H}(2) \mathrm{O}(2)$ and iodate. Biosens Bioelectron 29: 151-158.

22. Kumar AS, Swetha $P$ (2011) Simple adsorption of anthraquinone on carbon nanotube modified electrode and its efficient electrochemical behaviors. Colloids Surf A 384: 597-604

23. Kumar SA, Wang SF, Chang YT, Lu HC, Yeh CT (2011) Electrochemical properties of myoglobin deposited on multi-walled carbon nanotube/ ciprofloxacin film. Colloids Surf B Biointerfaces 82: 526-531.

24. Zhang J, Gao L (2010) Synthesis of Highly Dispersed Platinum Nanoparticles on Multiwalled Carbon Nanotubes and their Electrocatalytic Activity towards Hydrogen Peroxide. J Alloys Compd 505: 604-608.

25. Dursun Z, Gelmez B (2009) Simultaneous Determination of Ascorbic Acid Dopamine and Uric Acid at Pt Nanoparticles Decorated Multiwall Carbon Nanotubes Modified GCE. Electroanalysis 22: 1106-1114.

26. Wu K, Hu S (2004) Electrochemical determination of hydrogen sulfide at carbon nanotube modified electrodes. Microchim Acta 144: 131-137.

27. Jacobs CB, Peairs MJ, Venton B (2010) Carbon nanotube based electrochemical sensors for biomolecules. J Anal Chimica Acta 662: 105-127.

28. Liu Y, Lan D, Wanzhi W (2009) Layer-by-layer assembled DNAfunctionalized single-walled carbon nanotube hybrids-modified electrodes for 2,4,6-trinitrotoluene detection. J Electroanal. Chem 637: 1-5.

29. Kim YR, Bong S, Kang YJ, Yang Y, Mahajan RK, et al. (2010) Electrochemical detection of dopamine in the presence of ascorbic acid using graphene modified electrodes. Biosens Bioelectron 25: 2366-2369.

30. Chuan-yin Liu, Zhong-yong Liu, Rong Peng, Zhi-cheng Zhong, (2014) Quasireversible Process of Dopamine on Copper-Nickel Hydroxide Composite/ Nitrogen Doped Graphene/Nafion Modified GCE and Its Electrochemical Application. Journal of Analytical Methods in Chemistry 2014: Article ID 724538

31. Razmi H, Agazadeh M, Habibi-A B (2003) Electrocatalytic oxidation of dopamine at aluminum electrode modified with nickel pentacyanonitrosylferrate films, synthesized by electroless procedure. Journal of electro chemistry 547 25-33

32. Wu K, Fei J, Hu S (2003) Simultaneous determination of dopamine and serotonin on a glassy carbon electrode coated with a film of carbon nanotubes. Anal Biochem 318: 100-106.

33. Adekunle AS, Abdullahi MF, Pillay J, Kenneth IO, Bhekie B, et al. (2012) Electrocatalytic properties of prussian blue nanoparticles supported on poly $(\mathrm{m}$ aminobenzenesulphonic acid)-functionalised single-walled carbon nanotubes towards the detection of dopamine. Colloids and Surfaces B: Biointerfaces 95 186-194.

34. Maryam D, Tahoora J, Mojdeh E, Majedeh B, Roya S, et al. (2013) Synthesis and Characterization of $\mathrm{NiO}$ Nanoparticle as a High Sensitive Voltammetric Sensor for Vitamin C Determination in Food Samples. Int J Electrochem Sci 8: 8252-8263.

35. Sheo KM, Rajneesh KS, Prakash SG (2012) ZnO nanoparticles: Structural optical and photoconductivity characteristics. Journal of Alloys and Compounds 539: $1-6$

36. Fengdan J (2014) The Preparation of Glucan- $\mathrm{Fe}_{3} \mathrm{O}_{4}$ Magnetic Nanoparticles and Its In Vivo Distribution in Mice. J Chem 2014: 1-4.

37. Giovanelli D, Lawrence NS, Wilkins SJ, Jiang L, Jones TG, et al. (2003) Anodic stripping voltammetry of sulphide at a nickel film: Towards the development of a reagentless sensor. Talanta 61: 211-220.

38. Zagal J, Paez M, Tanaka AA, dos Santos Jr. JR, Linkous CA (1992) Electrocatalytic activity of metal phthalocyanines for oxygen reduction. Electroanal Chem 339: 13-30.

39. Assem B, Al-Noaimi M, Suleiman M, Abdullah SA, Hammouti B (2013) One Step Synthesis of NiO Nanoparticles via Solid-State Thermal Decomposition at Low-Temperature of Novel Aqua (2,9-dimethyl-1,10- phenanthroline) $\mathrm{NiCl}_{2}$ Complex. Int J Mol Sci 12: 23941-23954.

40. Dharmaraj N, Prabu P, Nagarajan S, Kimb CH, Park JH, et al. (2006) Synthesis of nickel oxide nanoparticles using nickel acetate and poly(vinyl acetate) 
Citation: Fayemi OE, Adekunle AS, Ebenso EE (2015) Metal Oxide Nanoparticles / Multi-walled Carbon Nanotube Nanocomposite Modified Electrode for the Detection of Dopamine: Comparative Electrochemical Study. J Biosens Bioelectron 6: 190. doi:10.4172/2155-6210.1000190

precursor. Materials Science and Engineering B 128: 111-114.

41. Satyanarayana T, Srinivasa RK, Nagarjuna G (2012) Synthesis, Characterization, and Spectroscopic Properties of $\mathrm{ZnO}$ Nanoparticles. ISRN Nanotechnology, 2012: 1-6.

42. Awodugba AO, llyas Abdul-Mojeed O (2013) Synthesis and characterization of $\mathrm{ZnO}$ nanoparticles with zinc chloride as zinc source. Asian journal of Natural \& Applied Sciences 2: 41-43.

43. Koutzarova T, Kolev S, Ghelev C, Paneva D, Nedkov I (2006) Microstructural study and size control of iron oxide nanoparticles produced by microemulsion technique. Phys Stat Sol 31: 1302-1307.

44. Sharif A, Ufana R, Ajeet K, Javed A (2009) Soft Template Synthesis of Super Paramagnetic $\mathrm{Fe}_{3} \mathrm{O}_{4}$ Nanoparticles a Novel Technique. J Inorg Organomet Polym

45. Xu Z, Gao N, Chen H, Dong S (2005) Biopolymer and carbon nanotubes interface prepared by self-assembly for studying the electrochemistry of microperoxidase-11. Langmuir 21: 10808-10813.

46. Bokobza L, Zhang J (2012) Raman spectroscopic characterization of multiwall carbon nanotubes and of composites. eXPRESS Polymer Letters 7: 601-608.

47. Liliane B, Jean-Luc B, Michel C (2013) Raman spectroscopic investigation of carbon-based materials and their composites. Comparison between carbon nanotubes and carbon black. Chemical Physics Letters 590: 153-159.

48. Cordoba-Torresi SI, Hugot-Le Goff A, Joiret S (1991) Electrochromic Behavior of Nickel Oxide Electrodes: II Identification of the Bleached State by Raman Spectroscopy and Nuclear Reactions. J Electrochem Soc 138: 1554-1559.

49. Slavov L, Abrashev MV, Merodiiska T, Gelev Ch, Vandenberghe RE, et al. (2010) Raman spectroscopy investigation of magnetite nanoparticles in ferrofluids. Journal of Magnetism and Magnetic Materials 14: 1904-1911.

50. Romcevic N, Kostic R, Romcevic M, Hadzic B, Kuryliszyn-Kudelska I, et al (2008) Raman Scattering from $\mathrm{ZnO}(\mathrm{Fe})$ Nanoparticles. Acta Physcica Polonica A 114: 1323-1328.

51. Hofmeister AM, Keppel E, Speck AK (2003) Absorption and reflection infrared spectra of $\mathrm{MgO}$ and other diatomic compounds. Mon Not R Astron Soc 345: 16-38

52. Shahrokhian S, Bozorgzadeh S, (2006) Electrochemical oxidation of dopamine in the presence of sulfhydryl compounds: Application to the square-wave voltammetric detection of penicillamine and cysteine. Electrochim. Acta 51: 4271-4276.

53. Al-baharani MR, Liu L, Ahmed W, Tao J, Tu F, et al. (2015) NiO- NF/MWCNT nanocomposite catalyst as a counter electrode for high performance dyesensitized solar cells. App Sur Sci 331: 333-338.

54. Gultekin D, Alaf M, Akbulut A (2013) Synthesis and characterization of $\mathrm{ZnO}$ nanopowders and $\mathrm{ZnO}-\mathrm{CNT}$ nanocomposites prepared by chemical precipitation route. Acta Physica Polonica A 123: 26

55. Sadegh H, Shahryari-ghoshekandi R, Kazemi M (2014) Study in synthesis and characterization of carbon nanotubes decorated by magnetic iron oxide nanoparticles. Int Nano Lett 4: 129-135.
56. Sahraoui Y, Chaliaa S, Maaref A, Haddad A, Jaffrezic-Renault N (2013) An Electrochemical Nitrite Sensor Based on a Multilayer Film of Polyoxometalate. J Sens Technol 3: 84-93.

57. Radhakrishnan S, Krishnamoorthy K, Sekar C, Wilson J, Kim S (2014) A highly sensitive electrochemical sensor for nitrite detection based on $\mathrm{Fe} 2 \mathrm{O} 3$ nanoparticles decorated reduced graphene oxide nanosheets. Appl Catal B 148-149: 22-28.

58. Cui AY, Yang C, Zeng W, Oyama M, Pu W, Zhang J (2007) Electrochemical determination of nitrite using a gold nanoparticles-modified glassy carbon electrode prepared by the seed-mediated growth technique. Anal Sci 23: 1421 1425.

59. Abolanle SA, Seonyane L, Portia LG, Tebogo PTs, Lukman OO, et al. (2015) Electrochemical response of nitrite and nitric oxide on graphene oxide nanoparticles doped with Prussian blue (PB) and Fe2O3 nanoparticles. RSC Adv 5: 27759

60. Wei Lai, Sossina M (2005) Impedance Spectroscopy as a Tool for Chemical and Electrochemical Analysis of Mixed Conductors: A Case Study of Ceria. J Am Ceram Soc 88: 2979-2997.

61. Tovide O, Jaheed N, Mohamed N, Nxusani E, Sunday CE, et al. (2014) Graphenated polyaniline-doped tungsten oxide nanocomposite sensor for real time determination of phenanthrene. Electrochim Acta 128: 138-148.

62. Min K, Yoo YJ (2009) Amperometric detection of dopamine based on tyrosinase-SWNTs-Ppy composite electrode. Talanta 80: 1007-1011.

63. Angeles GA, Lopez BP, Pardave MP, Silva MTR, Alegret S, et al. (2008) Enhanced host-guest electrochemical recognition of dopamine using cyclodextrin in the presence of carbon nanotubes. Carbon 46: 898-906.

64. Teo Peik-See, Alagarsamy P, Nay-Ming H, Hong-Ngee L, Sulaiman Y (2014) Simultaneous Electrochemical Detection of Dopamine and Ascorbic Acid Using an Iron Oxide/Reduced Graphene Oxide Modified Glassy Carbon Electrode. Sensors 14: 15227-15243.

65. Bard AJ, Faulkner LR (2001) Electrochemical methods. John Wiley \& Sons New York.

66. Soderberg JN, Co AC, Sirk AH, Birss VI (2006) Impact of porous electrode properties on the electrochemical transfer coefficient. J Phys Chem B 110: 10401-10410.

67. Hasanzadeh M, Khalilzadeh B, Shadjou N, Karim-Nezhad G, Lotfali L, et al. (2010) A New Kinetic-Mechanistic Approach to Elucidate Formaldehyde Electrooxidation on Copper Electrode. Electroanalysis 22: 168.

68. Xu Z, Gao N, Chen H, Dong S (2005) Biopolymer and carbon nanotubes interface prepared by self-assembly for studying the electrochemistry of microperoxidase-11. Langmuir 21: 10808-10813.

69. Refat FA, Gehad GM, Hala AM, (2012) Chemically Modified Carbon Paste Electrode for Determination of Cesium Ion by Potentiometric. Method American Journal of Analytical Chemistry 3: 576-586. 